\title{
Towards a toolbox for nationality legislation
}

Citation for published version (APA):

de Groot, G. (2016). Towards a toolbox for nationality legislation: Text of the Valedictory Lecture as Professor of Comparative Law and Private International Law at Maastricht University delivered on 14 October 2016. Nexuslegal. https://doi.org/10.26481/spe.20161014gg

Document status and date:

Published: 14/10/2016

DOI:

10.26481/spe.20161014gg

Document Version:

Publisher's PDF, also known as Version of record

\section{Please check the document version of this publication:}

- A submitted manuscript is the version of the article upon submission and before peer-review. There can be important differences between the submitted version and the official published version of record.

People interested in the research are advised to contact the author for the final version of the publication, or visit the DOI to the publisher's website.

- The final author version and the galley proof are versions of the publication after peer review.

- The final published version features the final layout of the paper including the volume, issue and page numbers.

Link to publication

\footnotetext{
General rights Owners
rights.

- You may freely distribute the URL identifying the publication in the public portal. please follow below link for the End User Agreement:

www.umlib.nl/taverne-license

Take down policy

If you believe that this document breaches copyright please contact us at:

repository@maastrichtuniversity.nl

providing details and we will investigate your claim.
}

Copyright and moral rights for the publications made accessible in the public portal are retained by the authors and/or other copyright owners and it is a condition of accessing publications that users recognise and abide by the legal requirements associated with these

- Users may download and print one copy of any publication from the public portal for the purpose of private study or research.

- You may not further distribute the material or use it for any profit-making activity or commercial gain

If the publication is distributed under the terms of Article $25 \mathrm{fa}$ of the Dutch Copyright Act, indicated by the "Taverne" license above, 
Prof. mr. Gerard-René de Groot Faculteit der Rechtsgeleerdheid

\section{Towards a toolbox for nationality legislation}




\section{Towards a toolbox for nationality legislation}

Text of the Valedictory Lecture as Professor of Comparative Law and Private

International Law at Maastricht University delivered on 14 October 2016

by

Gerard-René de Groot 
(C) Prof. Mr. Gerard-René de Groot

All rights reserved. No part of this book may be reproduced in any form or by any means, without prior written permission from the author.

Druk: Grafigroep Zuid, Swalmen

www.nexuslegal.nl 


\section{Table of contents}

1. Introductory remarks

1.1 A lifelong fascination for nationality law

1.2 An ever growing corpus of international standards on nationality law

1.3 The increase of comparative nationality law studies

1.4 How much freedom is left?

1.5 Nationality, genuine link and social identity

2. Examples of the toolbox structure

2.1 Acquisition of nationality based on parentage (ius sanguinis/ ius filiationis)

2.1.1 Case 1 Delayed DNA evidence

2.1.2 Relevant international standards

2.1.3 Choices to be made

2.1.4 Related grounds for acquisition and loss and related general issues

2.1.5 An assessment of case 1

2.2 Acquisition based on adoption

2.2.1 Case 2 A foreign adoption

2.2.2 Relevant international standards

2.2.3 Choices to be made

2.2.4 Related grounds for acquisition and loss and related general issues

2.2.5 An assessment of case 2

2.3 Loss of nationality due to residence abroad

2.3.1 Case 3 Loss of nationality during pending nationality proceedings

2.3.2 Relevant international standards

2.3.3 Choices to be made

2.3.4 Related grounds for acquisition and loss and related general issues

2.3.5 An assessment of case 3

2.4 Loss of nationality due to activities seriously prejudicial to the vital interests of the State

2.4.1 Case 4 Deprivation of nationality of terrorist fighters

2.4.2 Relevant international standards

2.4.3 Choices to be made

2.4.4 Related grounds for acquisition and loss and related general issues

2.4.5 An assessment of case 4 
2.5 Loss of nationality due to loss of family relationship

2.5.1 Case 5 A successful denial of paternity

2.5.2 Relevant international standards

2.5.3 Choices to be made

2.5.4 Related grounds for acquisition and loss and related general issues

2.5.5 An assessment of case 5

2.6 Procedural safeguards

2.6.1 Case 6 Deprivation of nationality due to identity fraud

2.6.2 Relevant international standards

2.6.3 Choices to be made

2.6.4 Relevant grounds for acquisition and loss and related general issues

2.6.5 An assessment of case 6

2.7 Protection of legitimate expectations

2.7.1 Case 7 Extension of naturalisation?

2.7.2 Relevant international standards

2.7.3 Choices to be made

2.7.4 Relevant grounds for acquisition and loss and related general issues

2.7.5 An assessment of case 7

3 Concluding observations

4 Some words of thanks

List of abbreviations of iinternational treaties, protocols and recommendations

Other Abbreviations

Glossary of Latin terms

Bibliography 


\section{Introductory remarks}

\subsection{A lifelong fascination for nationality law}

Ruit hora. ${ }^{1}$ Time runs quickly. This hour I will deliver my valedictory lecture as ordinary professor at Maastricht University. Nobody will be surprised that this lecture will deal with the subject of nationality law. For a considerable part of my academic career I have worked on publications in this field and on the related area of international family law.

It is today an appropriate occasion to reveal when and why I developed such a strong interest in this field of law. This actually happened when I was a teenager and for quite personal reasons. My interest in nationality law was triggered by some interesting cases dealing with the nationality position of several close relatives.

I had three aunts in Belgium. One of them had dual nationality²: she was Belgian by birth but also possessed Netherlands nationality ${ }^{3}$ by marriage. My second aunt always said that she was stateless. However, later I discovered that she was not de iure stateless, but rather that she had huge difficulties in being recognised as a national of the Netherlands by marriage after losing her Belgian nationality. As a matter of fact, she was de facto stateless. My third aunt was Belgian: she had acquired this nationality by marriage and by that fact lost her Netherlands nationality. But although she was a Belgian national, she did not have voting rights. As a Belgian by marriage, her position was equated with that of a person who had acquired nationality by a so-called ordinary naturalisation, which granted in fact only a second-class nationality. ${ }^{4}$

My older sister emigrated with her husband to California in the mid-fifties of the past century. My nieces and nephew were born in the USA as American citizens, but they possessed also Netherlands nationality. ${ }^{5}$ In the mid-sixties my sister and brother in law naturalised in the USA. They lost Netherlands nationality because of the voluntary acquisition of a foreign nationality. However, my nieces and nephew did not lose Netherlands nationality, because they were not included in the naturalisation of their parents due to the fact that they had already acquired U.S. citizenship at birth. ${ }^{6}$

\footnotetext{
1 "Time is running away"; personal motto of Hugo Grotius (1583-1645).

${ }^{2}$ The terms nationality and citizenship will be used interchangeably in this publication.

${ }^{3}$ In this publication the expression "Netherlands nationality" will be used in order to refer to the nationality of the Kingdom of the Netherlands. The expression "Netherlands nationality" is preferred above the confusing expression "Dutch nationality".

${ }^{4}$ Note that the distinction between the ordinary naturalisation (naturalisation ordinaire) and the full naturalisation (naturalisation grande) was only abolished in 1993.

${ }^{5}$ Compare case C20 in De Groot 2007a, 167-178.

${ }^{6}$ They lost Netherlands nationality on 1 January 1995 by ten years of residence abroad in the country of their birth and being also in possession of the nationality of that country (Art. 15 lit. c Rijkswet op het Nederlanderschap (hereinafter: RwNed) as in force from 1985-2003). On that day also my Belgian-Netherlands aunt lost her Netherlands nationality by the operation of the same article.
} 
Yet another nationality issue in my family was the position of the second husband of my maternal grandmother. Although he was born in the Netherlands and possessed only Netherlands nationality, he lost this by residing ten years in Belgium, because he forgot to lodge the required declaration of prolongation. He became de iure stateless. ${ }^{7}$

It is obvious that my first steps in the field of nationality law were in light of these cases very much an experience of PBL ("Problem Based Learning"). ${ }^{8}$

A more systematic study of nationality law started after I finished my law studies at Groningen University in 1973 and received a scholarship to study in Germany. At that time German lawyers and politicians discussed the question how to implement the principle of equal treatment of men and women in nationality law. ${ }^{9}$ I was fascinated by that discussion and wrote an article on the desirability to modify also Netherlands nationality law in order to bring this in conformity with the equality principle. ${ }^{10}$ This article was the basis for my first book dealing with the equality of men and women in nationality law in comparative perspective, written on the invitation of the Netherlands Association of Comparative Law. ${ }^{11}$

Since that time I have continued to work in the field of nationality law. The focus of my publications changed during the course of time. However, one topic was always present: from the seventies to today several publications deal with the issue of whether or not having multiple nationalities is desirable. Moreover, since the early 1990s the relationship between the nationality of a Member State of the European Union and European citizenship became important. Consequently, the question whether EU law has relevancy for the grounds of acquisition and loss of nationality came to occupy a prominent place on the research agenda. For about fifteen years, special emphasis has been given to the issue of the reduction of statelessness. And more recently, several publications in the last ten years have dealt with the ban on arbitrary deprivation of nationality. It is striking that although the principle prohibiting the arbitrary deprivation of nationality was enshrined in the Universal Declaration of Human Rights three years before my birth, little attention was devoted, until recently, to the question how this prohibition should operate in practice.

\footnotetext{
${ }^{7}$ This happened between 1903 and 1910 due to the operation of Art. 7 (5) Wet op het Nederlanderschap en het ingezetenschap as in force from 1893-1910).

${ }^{8}$ Note that PBL is the basis of the teaching approach of Maastricht University. See http://www.maastrichtuniversity. $\mathrm{nl} / \mathrm{web} /$ Main/Education/ProblemBasedLearning.htm.

${ }^{9}$ The equal treatment of men and women was finally introduced in German nationality law on 1 January 1975 . See Reichs- und Staatsangehörigkeitsänderungsgesetz of 20 December 1974, Bundesgesetzblatt 1974 I, 3714. Note also the judgment of the German Constitutional Court (Bundesverfassungsgericht) 21 May 1974, BVerfGE 37, $217-264$.

${ }^{10}$ De Groot 1975.

${ }^{11}$ De Groot 1977.
} 


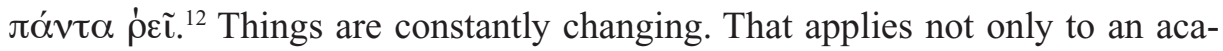
demic career, but also to nationality law as such.

Traditionally, nationality law was within the domaine réservé of States. ${ }^{13}$ States were autonomous in nationality matters. However, during the past five decades many international standards were developed regarding the rules of acquisition and loss of nationality. Some important steps have to be briefly mentioned ${ }^{14}$ :

The 1961 Convention on the Reduction of Statelessness (hereinafter : CRS) $)^{15}$ entered into force 41 years ago. Racial discrimination was expressly prohibited in the International Convention on the Elimination of All Forms of Racial Discrimination of 1966 (hereinafter: CERD). ${ }^{16}$ The equal treatment of men and women was prescribed in the 1979 Convention on the Elimination of all Discrimination of Women (hereinafter: CEDAW) ${ }^{17}$ Ten years later, in 1989, the Convention on the Rights of the Child (hereinafter: $\mathrm{CRC})^{18}$ was adopted. All these Conventions contain provisions with high relevancy for nationality law.

At the regional level the European Convention on Nationality of 1997 (hereinafter: $\mathrm{ECN})^{19}$ is of paramount importance, being the first comprehensive nationality convention in the world. ${ }^{20}$ But also Art. 20 of the 1969 American Convention on Human Rights (hereinafter: AmCHR) ${ }^{21}$, Art. 6 of the 1990 African Charter on the Rights and Welfare of the Child (hereinafter: ACC) ${ }^{22}$, Art. 24 of the 1995 Commonwealth of Independent States Convention on Human Rights and Fundament Freedoms (hereinafter CISC) ${ }^{23}$ and Art. 29 of the 2004 Arab Charter on Human Rights (hereinafter: ArCHR) ${ }^{24}$ fit in this list. ${ }^{25}$

In addition to these treaties significant soft law instruments have been adopted. At the global level the UNHCR Guidelines on statelessness which were published between 2012-2015 ${ }^{26}$ are influential. Also the 2009 Report of the UN

\footnotetext{
12 "Everything flows"; this aphorism was used by Simplicius (c. 490-560) in order to characterise the thoughts of Heraclitus (c. 535-475 BC).

${ }^{13}$ See inter alia Art. 1 of the Hague Convention on Certain Questions relating to the Conflict of Nationality Law (HCNL), LNTS 179, 89.

${ }^{14}$ See for a comprehensive overview of all relevant rules De Groot/ Vonk $2016 \mathrm{~b}$.

${ }^{15}$ UNTS 989, 175.

${ }^{16}$ UNTS 660, 195.

${ }^{17}$ UNTS 1249, 13.

${ }^{18}$ UNTS 1599, 3.

${ }^{19}$ CETS 166.

${ }^{20}$ Note also the 2006 Council of Europe Convention on the Avoidance of Statelessness in Relation to State Succession (ECSS), which develops some principles already enshrined in the ECN for the state succession context.

${ }^{21}$ OAS Treaty Series No. 36; UNTS 1144, 123.

${ }^{22}$ OAU Doc. CAB/LEG/24.9/49 (1990).

${ }^{23}$ www.refworld.org/docid/49997ae32c.html.

${ }^{24}$ www1.umn.edu/humanrts/instree/loas2005.html?msource=UNWDEC19001\&tr=y\&auid=3337655

${ }^{25}$ See also Art. 7 of the 2005 Covenant of the Rights of the Child in Islam (available on: http://www.refworld.org/ docid/44eaf0e4a.html )www.refworld.org/docid/44eafOe4a.html andArt. 18 of the 2012 ASEAN Declaration of Human Rights (available on: www.thecambodiaherald.com/cambodia/full-text-of-asean-human-rights-declaration-2773).

${ }^{26}$ The UNHCR Guidelines on statelessness 1-3 are now included (with some minimal changes) in the 'Handbook
} 
Secretary General to the Human Rights Council on arbitrary deprivation of nationality is pivotal. ${ }^{27}$ In the European context the Council of Europe Recommendation 2009/13 of the Committee of Ministers on the nationality of children ${ }^{28}$ deserves attention.

And the work goes on: in the African context a Nationality Protocol to the African Convention on Human and Peoples Rights ${ }^{29}$ will, it is hoped, soon be adopted. After adoption and entry into force that Protocol will be the most comprehensive international instrument in the field of nationality law. ${ }^{30}$

Of course, the treaties just mentioned are strictly spoken only binding for States that acceded to these conventions. Soft law documents are even less binding. But all these documents have at least a persuasive character. Together they constitute the framework of international standards within which States should draw the picture of their nationality rules.

In the recent past important case law limited - in particular in the European context $^{31}$ - the autonomy of States in nationality matters. In the landmark decision in Genovese v Malta ${ }^{32}$ the European Court of Human Rights (hereinafter: ECtHR) came to the conclusion that citizenship is a part of the social identity of a person which is as such protected under the concept of private life of Art. 8 of the European Convention on Human Rights (hereinafter: ECHR). The access to citizenship has therefore to be regulated in a non-discriminatory way. ${ }^{33}$ It is very likely that the message of the ECtHR in Genovese v Malta also has consequences for the regulation of the loss of citizenship. ${ }^{34}$

\footnotetext{
on protection of stateless persons under the 1954 Convention relating to the Status of Stateless Persons'; see http:// www.refworld.org/docid/53b676aa4.html. The UNHCR Guidelines on statelessness No. 4 (on the interpretation of the Articles 1-4 of the 1961 CRS) can be consulted on http://www.refworld.org/docid/50d460c72.html . The UNHCR Guidelines on statelessness No. 5 (on the interpretation of the Articles 5-9 of the 1961 CRS) will be published soon. ${ }^{27}$ UN Human Rights Council, Human rights and arbitrary deprivation of nationality: report of the Secretary-General, 14 December 2009, A/HRC/13/34, available on http://www.refworld.org/docid/4b83a9cb2.html (hereinafter: SG UN 2009). See also UN Human Rights Council, Human rights and arbitrary deprivation of nationality: Report of the Secretary-General, 19 December 2013, A/HRC/25/28, available on http://www.refworld.org/docid/52f8d19a4.html (hereinafter: SG UN 2013).

${ }^{28} \mathrm{http} / / /$ www.coe.int/t/dghl/standardsetting/cdcj/CDCJ\%20Recommendations/CMRec(2009)13E_NationaliteDesEnfants. pdf See on Rec. 2009/13 De Groot 2014a.

${ }^{29}$ Manby 2015, 462-466.

${ }^{30}$ Note also the 1999 Draft Articles on Nationality of Natural Persons in Relation to the Succession of States prepared by the ILC.

${ }^{31}$ However, note also for the Americas inter alia Case of the Yean and Bosico Children v. The Dominican Republic, Inter-American Court of Human Rights (IACrtHR), 8 September 2005, available at: http://www.refworld.org/ docid/44e497d94.html and for Africa: Institute for Human Rights and Development in Africa (IHRDA) and Open Society Justice Initiative (on behalf of Children of Nubian Descent in Kenya) v. the Government of Kenya, Decision No 002/Com/002/2009, African Committee of Experts on the Rights and Welfare of the Child (ACERWC), 22 March 2011, available at: http://www.refworld.org/docid/4f5f04492.html .

${ }^{32}$ ECtHR 11 October 2011 (application no. 53124/09). See De Groot/ Vonk 2012.

${ }^{33}$ See also ECtHR 26 June 2014 in Labassee (no. 65941/11) and in Mennesson (application no. 65192/11).

${ }^{34}$ In other words, nationality is now protected under the ECHR and also under the ACC, AmCHR, ArCHR and CISC.
} 
The Court of Justice of the European Union (hereinafter: CJEU) concluded in Janko Rottmann ${ }^{35}$ that deprivation of the nationality of a Member State of the European Union with statelessness as a consequence may only happen after a European proportionality test. It is likely that also other general principles of European law, like e.g. the equality principle and the principle of protection of legitimate expectation limit the power of Member States in nationality matters. ${ }^{36}$

\subsection{The increase of comparative nationality law studies}

In the past decades comparative studies on nationality law increased in volume and, thanks to the cooperation of lawyers, political scientists, sociologists and others, acquired more depth. ${ }^{37}$ Now we have a considerably better and more detailed overview of the huge variety of rules in this field. The most important achievement is the EUDO CITIZENSHIP Global Database on Modes of Acquisition and Loss of Citizenship (hereinafter: Eudo-citizenship database) ${ }^{38}$ Linked to that database several research projects deepened our understanding of comparative nationality law, such as ACIT ${ }^{39}$ and ILEC..$^{40}$

Several of these projects try to assess to what extent the laws of States are in accordance with the international standards following from treaties and other international instruments. ${ }^{41}$

\subsection{How much freedom is left?}

In light of these developments we now should ask what kind of choices States have to make when regulating their nationality law. How much freedom do they still enjoy in light of those standards? Between which alternatives choices have to be made? And what are the advantages and disadvantages of available options?

The time is ripe to develop a kind of toolbox for nationality legislation in order to facilitate discussions on national level between stakeholders involved in nationality law reform, but also in order to enhance discussions on international level in view of developing new, more detailed standards. What should such a toolbox look like?

\footnotetext{
${ }^{35}$ ECJ 2 March 2010, C-135/08. See De Groot / Seling 2010.

${ }^{36}$ AG Poiares Maduro in his opinion (30 September 2009) in Rottmann, para. 28-32.

${ }^{37}$ Aleinikoff and Klusmeyer 2000; Faist and Kivisto 2007; Hansen and Weil 2001; Pitkänen and Kalekin-Fishman 2007.

${ }^{38} \mathrm{http}$ ://eudo-citizenship.eu/databases.

${ }^{39}$ Access to Citizenship and its Impact on Immigrant Integration (ACIT); see http://eudo-citizenship.eu/about/acit.

${ }^{40}$ Involuntary Loss of European Citizenship (ILEC); see http://www.ilecproject.eu/. See also Carrera/ De Groot 2015.

${ }^{41}$ See e.g. the ILEC Guidelines 2015, available on http://www.ilecproject.eu/sites/default/files/GUIDELINES\%20 INVOLUNTARY\%20LOSS\%20OF\%20EUROPEAN\%20CITIZENSHIP\%20.pdf, also in Carrera Nuñez- De Groot 2015, 595-602.
} 
For all possible grounds of acquisition and loss of nationality the toolbox should first describe the relevant international standards. Subsequently, it has to indicate how much room is left for States to create their own rules, which choices have to be made and the consequences that the different choices entail. Sometimes the choice for a certain rule implies consequences for other potential nationality law rules: if a country makes a choice in favour of a rule that all children born on the territory acquire the nationality of the country (ius soli), there is no need for a default rule facilitating the access to the nationality of the country of birth for otherwise stateless children. In other cases the choice may have consequences beyond nationality law: e.g. deprivation of nationality because of terrorist activities may reduce the international criminal jurisdiction of the country involved.

In order to illustrate the proposed toolbox, I propose to give seven examples:

- Acquisition of nationality based on parentage (ius filiationis/ ius sanguinis)

- Acquisition of nationality based on adoption

- Loss of nationality due to residence abroad

- Loss of nationality due to activities seriously prejudicial to the vital interests of the State

- Loss of nationality due to loss of a family relationship

- Procedural safeguards

- Protection of legitimate expectations

The first five categories are closely related to so-called modes of acquisition and loss of nationality as identified and listed in the Eudo-citizenship database. ${ }^{42}$ The sixth and seventh examples have a more general character. Procedural safeguards are of importance for all grounds for acquisition and loss, whereas the protection of legitimate expectations can play a role in respect of most grounds for acquisition.

The toolbox can be seen as a way to consolidate the existing international standards in an accessible way. However, it should not take the shape of a kind of model code of nationality. In the sensitive field of nationality - where States often have very strong and explicit feelings - such a code would go too far. However, the toolbox should facilitate the debate between nationality law policy makers: a good picture of relevant rules on international level should be offered ${ }^{43}$, together with an analysis of alternatives between which choices should be made on national level. Descriptions of good and bad practices should complete the picture.

\footnotetext{
${ }^{42}$ See http://eudo-citizenship.eu/databases.

${ }^{43}$ It is of course obvious that in the national debate it matters considerably whether a State is bound by certain international standards because they are enshrined in a treaty to which the State involved is a Contracting Party, or whether the status of an international rule is only persuasive due to the fact that it is part of a treaty to which this State did not accede or can be found in an international soft law instrument.
} 


\subsection{Nationality, genuine link and social identity}

Before describing in more detail the structure of the toolbox which I propose, some general remarks on nationality and nationality law are appropriate.

The nationality of a person indicates that an important link exists between this person and the State of nationality. This link is often described as genuine link or genuine connection ${ }^{44}$ The basis of this genuine link can be a parentage tie with a national of that State, birth on its territory or having lived there for a considerable period of time. In the course of the life of a person (s)he may lose the link with the State of her or his nationality. This may lead to the loss of nationality but the international standards - as they are now interpreted - do in principle not allow a loss of nationality leading to statelessness.

If a person has a genuine link with a State, (s)he should have access to that State's nationality in a non-discriminatory way. This follows inter alia from the 2011 ECtHR ruling in Genovese v Malta. In that case the genuine link was parentage. The child claiming access to Maltese nationality had a Maltese father, but was born out of wedlock. For that reason he did not have access to the nationality of his father. As mentioned above, the Court stated that the nationality of a person is part of her or his social identity and as such protected under the notion of "private life" as laid down in Art. 8 ECHR. However, one should realise that the child did not yet possess Maltese nationality, but was claiming access to that nationality. In other words, if there is a relevant genuine link with a State - like in Genovese v Malta via parentage - the access to the nationality of the State has to be given in a non-discriminatory way. Children born in wedlock and those born out of wedlock have to be treated equally.

In my opinion we can apply the reasoning of the ECtHR in Genovese v Malta to other types of genuine links with a State. ${ }^{45}$ Consequently, also the access to the nationality of a State with which a person has a genuine link based on birth on the territory or by living there for a long period should be given in a non-discriminatory way and the denial of such access should be open to administrative or judicial review. The grounds for a denial should be proportionate.

The existence of a genuine link in connection with the principle of proportionality is also essential for grounds for loss. In principle, no loss of nationality should occur if there is evidently a genuine link between the person involved and the State of nationality. Even in the case of deprivation of nationality due to fraud, the fact of an existing genuine link is an important factor which has to be taken into account in the context of a proportionality test. ${ }^{46}$

\footnotetext{
${ }^{44}$ ICJ 6 April 1955 in Nottebohm, ICJ Reports 1955, 4.

${ }^{45}$ Note that the ECtHR based the protection of the access to nationality on "private life" and not on "family life". "Family life" requires a tie with another person (e.g. by parentage), whereas "private life" can encompass all kinds of circumstances.

${ }^{46}$ ECJ 2 March 2010, C-135/08 in Rottmann, para. 55.
} 
To sum up: there is an intimate relationship between the social identity of a person as part of her or his private life and the genuine link between a person and a State which is manifested by the nationality of that State. This relationship has to be kept in mind while writing on or even developing international standards in the field of nationality law and also if one assesses national rules on grounds of acquisition and loss of nationality. 


\section{Examples of the toolbox structure}

Hereinafter the structure of the proposed toolbox will be illustrated by giving seven examples. In order to make this presentation more lively, each of the examples of the toolbox structure will be introduced by the description of a problematic case, which will also be briefly assessed in light of the international standards described in the toolbox.

\subsection{Acquisition of nationality based on parentage (ius sanguinis/ius filiationis)}

\subsubsection{Case 1 Delayed DNA evidence}

Arthur Amsingh, a man of Netherlands nationality, recognises Brian, born in Surinam out of wedlock as the child of a Surinamese mother. Due to the fact that Brian had already reached the age of seven years at the time of the recognition, he did not automatically acquire Netherlands nationality by becoming the son of a Netherlands father. This nationality will only be acquired if the biological truth of the recognition is proven by submitting a DNA-report within one year after the recognition ${ }^{47}$ Arthur asked at the Embassy of the Netherlands where such a report could be ordered. An address of an institute was provided. A couple of months later Arthur proudly submits the report - confirming that he is with 99,9\% certainty the biological father of Brian - to the Embassy, but the officer in charge nevertheless refuses the report, because the institute involved is not accredited according the relevant international standards. Arthur now requests a report of an accredited institute. Again after a couple of months he submits a report of the accredited institution, also confirming the biological truth of the recognition. But the Embassy refuses again to issue a Netherlands passport for Brian, because he did not acquire Netherlands nationality due to the fact that the second report was submitted more than one year after the recognition! ${ }^{48}$

\subsubsection{Relevant international standards}

A child has the right to acquire the nationality of a parent but States may make exceptions for children born abroad and may provide for a special procedure for children born out of wedlock. ${ }^{49}$ However, if the child would otherwise be stateless the child must always automatically acquire the nationality of the parent, also in case of birth abroad. ${ }^{50}$ What is more, a State may never make a distinction based on the maternal or paternal parentage. ${ }^{51}$ In other words, the acquisition of nationality through the father (ius sanguinis a patre) needs to happen under the same conditions as the acquisition of nationality through the mother (ius

\footnotetext{
${ }^{47}$ See Art. 4 (3) RwNed as in force since 2009.

${ }^{48}$ The case description is based on an e-mail I received from the lawyer of the father. For reasons of privacy, the names of the individuals concerned have been changed throughout this lecture. Compare also the judgment of the Court of The Hague (Rechtbank Den Haag) 25 February 2016, ECLI:NL:RBDHA:2016:2305.

${ }^{49}$ Art. 6 ECN; Principle 10 Rec. 2009/13.

${ }^{50}$ Principle 1 Rec. 2009/13.

${ }^{51}$ Art. 9(2) CEDAW; ECtHR 11 October 2011 in Genovese v Malta.
} 
sanguinis a matre. Moreover, a State may never regulate any ground for acquisition of nationality in a way which would result in ethnic, racial or religious discrimination..$^{52}$

A State may provide that a child of a national born abroad only acquires the nationality of this parent if a) both parents are nationals; b) both parents lodge a joint declaration; or c) one parent lodges a declaration. ${ }^{53}$ A State may also differentiate between the first, second and subsequent generations born abroad.

Parent is a person who acquired this status under the law of the State involved or under foreign law but recognised in the State involved. It does not matter whether the legal status of parent is based on genetic truth. A State shall not make the acquisition of nationality by parentage conditional on evidence of the biological truth if this evidence was not yet a condition for the establishment of the parentage. ${ }^{54}$ Furthermore, if the parentage established abroad between a child born by a surrogate mother with an intending parent is recognised by the State of nationality of this parent, the child must have access to the nationality of the intending parent under the same conditions as a child born to this parent..$^{55}$ In other words, it is not the "blood" (sanguis) of a child that matters for the acquisition of nationality but the legal tie of parentage (filiatio). It is for that reason considerably better to use the expression ius filiationis instead of the old-fashioned ius sanguinis. ${ }^{56}$

\subsubsection{Choices to be made}

As mentioned above, States have to decide whether they want to restrict the acquisition of the nationality by parentage in cases of birth abroad. A reason to do so will be the assumption that a child born abroad will not build sufficiently close ties with the State of nationality of the parent to justify the attribution of nationality. ${ }^{57}$ However, an alternative for limiting the acquisition of nationality in the case of birth abroad is to provide for loss of nationality because of residence abroad by a person born abroad and living permanently abroad during a certain number of years after having attained the age of majority.$^{58}$ An obvious advantage of this alternative is the fact that the child can decide to build up ties with the country of nationality in order to avoid the loss of nationality.

A disadvantage of limiting the acquisition of nationality by parentage in case of birth abroad or to make this conditional on the consent of both parents creates

\footnotetext{
${ }^{52}$ Art. 5 ECN, Art. 5 CERD, Art. 9 CRS.

${ }^{53}$ Art. 6 ECN.

${ }^{54}$ Principle 10 Rec. 2009/13.

${ }^{55}$ Principle 11 Rec. 2009/13 and para. 32 of the Explanatory Memorandum on this Recommendation. Compare also ECtHR 26 June 2014 in Labassee and in Mennesson. See on the nationality status of children arising from intercountry surrogacy arrangements Wells-Greco 2015.

${ }^{56}$ See Bauböck 2015, David de Groot 2015 and Eva Ersbøll 2015.

${ }^{57}$ Vink/De Groot 2010a and 2010b.

${ }^{58}$ De Groot/Vink 2014, para. 6 and table 3.5. See hereinafter para. 2.3.
} 
problems in respect of diplomatic and consular protection of the child in case of (parental) child abduction. If the child does not acquire the nationality of a parent because of a general limitation of the transfer of nationality at birth in case of birth abroad or because the non-national parent refuses to give the required consent for the acquisition of nationality and the parents split up the parent whose nationality the child does not possess may be legally prejudiced in requesting diplomatic or consular assistance of her or his own State if the child is abducted to another country.

To make the acquisition of nationality of a parent by the child in case of birth abroad conditional on the registration as a national on the request of a parent is also not unproblematic. The first problem is whether a State is entitled to provide that only the national-parent can request such registration. A negative answer seems to be appropriate. ${ }^{59}$ If the parentage is established against the will of the parent involved (s)he may be tempted not to register the child in order to avoid the child developing nationality ties with the State involved.

Making the acquisition of nationality conditional on the registration by either parent is less problematic but one should realise that later in life the child will perhaps not share the 'reasons' of the parent(s) for non-registration. The reason for non-registration may be indifference, lack of information on the necessity to register, or may be of a more serious nature. Be this as it may, it is not difficult to imagine that children may be of a different opinion and may develop a huge interest in acquiring the nationality of the parent. In that light it is attractive to offer the child a window to register as a national also during a certain period after having attained the age of majority. ${ }^{60}$ In favour of this solution is the fact that the child as a young adult is no longer subject to the parental authority of the parent(s). A disadvantage of this solution is evidently that the child would also be able to register as a national if until that moment no ties where developed with the country involved.

A disadvantage of allowing registration of the child as national by only one parent can also be problematic if the child already acquired ex lege the nationality of the country of the other parent. If this other state classifies the acquisition of nationality by registration as voluntary acquisition of a foreign nationality, this may trigger the loss of the first acquired nationality. ${ }^{61}$

A related issue is the following. Quid iuris if the parentage tie was only established after having attained the age of majority? Most legal systems provide only for acquisition of nationality by parentage, if this parentage was established

\footnotetext{
${ }^{59}$ De Groot/Vonk 2012 conclude this from the ruling of the ECtHR 11 October 2011 in Genovese v Malta.

${ }^{60}$ Compare Art. 1(2)(a) 1961 Convention. See De Groot 2012a.

${ }^{61}$ See for an example on the loss of Norwegian nationality by the child of a Norwegian mother and an Australian father due to the registration of the child as an Australian national: http://statsborger.no/en/how-nina-cannot-livetogether-with-her-kids-in-norway/ .
} 
during the minority of the child. ${ }^{62}$ However, some States provide for a different age limit $^{63}$ or an alternative access to nationality instead of an automatic acquisition (for example registration within a certain period) after the establishment of the parentage. ${ }^{64}$ These alternatives are in particular welcome in cases where e.g. a mother made an arrangement (often against payment) with the biological father not to establish the paternity. If the child is not able to start as a minor the procedure for a judicial establishment of paternity, the child would be deprived of the possibility to acquire the nationality of his father by parentage in case (s) he has to wait until having attained the age of majority. Giving the young adult an own window to acquire the nationality of the father seems to be appropriate.

Again another issue arises if the State provides for acquisition of nationality iure filiationis but documentary evidence on the parentage is lacking. It is certainly a best practice that Austria allows in such cases proof of parentage by DNA-evidence. ${ }^{65}$ It is questionable, however, whether the rule that the person involved has to pay the costs of the DNA-test can be recommended with respect to less wealthy States.

\subsubsection{Related grounds for acquisition and loss and related general issues}

The acquisition of nationality by parentage is in the Eudo-citizenship database subdivided into three categories: 1) birth in the country as child of a national, 2) birth abroad as child of a national and 3 ) establishment of parentage after birth. ${ }^{66}$ For academic comparative law purposes this subdivision is very useful but we can observe that several legal systems regulate the three categories by one rule: the child of a national parent is a national. For that reason, these different (sub) categories have to be presented together in the tool box.

A related ground for acquisition of nationality is adoption. ${ }^{67}$ It has been mentioned that parentage as a ground for acquisition of nationality should not depend on how this parentage is established and it should be irrelevant whether or not the parentage reflects the biological truth. Insofar there seems to be a justification to present adoption as a subcategory of parentage. However, three reasons lead to the conclusion that a separate discussion of adoption is to be preferred. First, not all adoptions replace the original parentage tie completely by a parentage tie with the adoptive parents. Second, some attention has to be given to defective adoption procedures, i.e. those cases where a child was residing in a

\footnotetext{
${ }^{62}$ Eudo-citizenship database mode A04.

${ }^{63}$ Para. 4(1) StAG: the parentage must be established by recognition or the procedure requesting judicial establishment of paternity must be initiated before the young adult reached the age of 23 years.

${ }^{64}$ Art. 17(2) Cc esp.: the young adult has an option right to Spanish nationality during a period of two years after the establishment of paternity.

${ }^{65}$ Para. 5(2) StBG.

${ }^{66}$ Modes of acquisition A01a (birth in the country as child of a national), A01b (birth abroad as child of a national) and A04 ("establishment of paternity"). The label of A04 is slightly problematic in light of the fact, that some legal systems also provide for the establishment of maternity (see e.g. Art. 1:207 Civil Code of the Netherlands (Burgerlijk Wetboek) as in force since 1 April 2014). For that reason a label "establishment of parentage" would be preferable.

${ }^{67}$ Eudo-citizenship database mode A10.
} 
particular state with a view of being adopted but the adoption was not finalised. Third, in case of intercountry adoption most adopted children are born abroad. This very important issue will be further discussed in the next chapter. ${ }^{68}$

It was already mentioned above that loss due to permanent residence abroad is related. ${ }^{69}$

Another related ground for loss is loss of nationality due to loss of the family relationship which was the basis for the acquisition. ${ }^{70}$

A huge difficulty may arise if the nationality of a person is based on the parentage tie with a national (iure filiationis) and after many years the authorities discover that this parentage tie did never exist. We are then confronted with so-called quasi-loss of nationality: in many States the authorities will conclude that the nationality was never acquired but the person involved will experience this "non-acquisition" as a loss of nationality. ${ }^{71}$ This issue is closely linked to the need to protect legitimate expectations. ${ }^{72}$

\subsubsection{An assessment of case 1}

It follows from the international standards described above, in particular from Recommendation 2009/13 and its Explanatory report, but also from the ECtHR decision in Genovese v Malta that the requirement of submitting a DNA-report proving the biological truth of the recognition as a condition for the acquisition of nationality of the father is not in conformity with the international standards. Given the fact that according to the law of the Netherlands recognition establishes a parentage tie also if it is not in conformity with the biological truth, it is not acceptable to require the fulfilment of the additional substantive requirement of submitting DNA-evidence on the biological truth in order to acquire Netherlands nationality. The legislator of the Netherlands should therefore remove this requirement or - alternatively - should introduce the requirement of the biological truth already in its family law. A judge dealing with a case as described above could in light of the Genovese $\mathrm{v}$ Malta ruling conclude that the nationality of the Netherlands is automatically acquired by the recognition. This is indeed reasonable, as it is unclear which goal is served by requiring that the evidence is submitted within one year. ${ }^{73}$

\footnotetext{
${ }^{68}$ See para. 2.2 .

${ }^{69}$ Eudo-citizenship database mode L02. See hereinafter, para. 2.3.

${ }^{70}$ Eudo-citizenship database mode L13a. See hereinafter, para. 2.5.

${ }^{71}$ De Groot/Wautelet 2014.

${ }^{72}$ This will be further elaborated in para. 2.7.

${ }^{73}$ The argumentation of the Court of the Hague 25 February 2016, ECLI:NL:RBDHA:2016:2305 that the time limit serves the legal certainty is - to put it mildly - far from convincing (see para. 5.3 of the judgment). It is furthermore striking that the transitory provision of Art. II of the Kingdom Act of 27 June 2008, Stb. 2008, 270 also requires the submission of DNA-evidence in order to acquire Netherlands nationality for a recognised child, but without any limitation in time! Because of this inconsequent attitude of the Netherlands, it is highly unlikely that the ECtHR would accept any argumentation as justification of the additional requirement of DNA evidence of the biological truth within one year after the recognition.
} 


\subsubsection{Case 2 A foreign adoption}

Berend Bodewes and Caroline Claassen, two spouses of Netherlands nationality living abroad, adopt a girl, Dorothy, in 1990. After the adoption is completed they successfully ask the Embassy of the Netherlands to issue a passport for the child. 25 years - and five passports - later an application by Dorothy for a new passport is rejected with the argument that she did never acquired Netherlands nationality by the adoption. Until 1998 only an adoption by decision of a court in the Netherlands was a ground for acquisition of nationality. Since 1998 an adoption in a Contracting State to the Hague Intercountry Adoption Convention also has nationality consequences, whereas since 2004 the recognition of an adoption in other countries can have as a consequence that Netherlands nationality is acquired. However, regrettably transitory rules favouring the acquisition of nationality in case of foreign adoptions realised before 1998, respectively 2004 are completely lacking. Furthermore, the Supreme Court of the Netherlands (Hoge Raad) as well as the Council of State as Supreme Administrative Court repeatedly stressed, that Netherlands nationality cannot be acquired on the basis of protection of legitimate expectations ${ }^{74}$.

\subsubsection{Relevant international standards}

In respect of acquisition of nationality by adoption - surprisingly - not many rules exist. Art. 6(4)(d) ECN provides that states shall facilitate the acquisition of their nationality for children adopted by one of their nationals. The same rule is included in Art. 12 of the 2008 European Convention on the Adoption of Children (revised) (hereinafter ECAC). However, neither of these conventions prescribes concrete ways for this to take place and the conditions which may be required.

In the case of adoption, a family relationship is created between the adopted child and his or her adopter(s). As a consequence of this newly created legal parentage, the adopted child's legal position should, also in respect of nationality law, as far as possible, be identical to the position of a biological child of the parent(s). This is inter alia prescribed by the Hague Convention on protection of children and co-operation in respect of intercountry adoption of 29 May $1993^{75}$ (Hague Adoption Convention; hereinafter HAC) as well as by Art. 11(1) ECAC 2008 (revised). That provision provides that:

"Upon adoption a child shall become a full member of the family of the adopter(s) and shall have in regard to the adopter(s) and his, her or their family the

\footnotetext{
${ }^{74}$ This case description is based on three different, but similar cases. Two of these cases were brought to my attention by the lawyers of the adopted children involved, the third case was sent to me by a registrar of civil status. In the latter case the person, adopted as a child, had already reached the age of 59 years and had been constantly in possession of a Netherlands passport. In the other two cases the adopted persons were young adults.

${ }^{75}$ Available on https://www.hcch.net/en/instruments/conventions/full-text/?cid=69.
} 
same rights and obligations as a child of the adopter(s) whose parentage is legally established." ${ }^{\prime 76}$

Art. 26(2) HAC 1993 provides:

"In the case of an adoption having the effect of terminating a pre-existing legal parent-child relationship, the child shall enjoy in the receiving State, and in any other Contracting State where the adoption is recognised, rights equivalent to those resulting from adoptions having this effect in each such State."

In September 2005, the Special Commission on the practical operation of the Hague Adoption Convention (established pursuant to a decision of the Hague Conference on Private International Law), adopted a set of Recommendations, of which Recommendation No. 17 dealt with nationality:

17. The Special Commission recommends that the child be accorded automatically the nationality of one of the adoptive parents or of the receiving State, without the need to rely on any action of the adoptive parents. Where this is not possible, the receiving States are encouraged to provide the necessary assistance to ensure the child obtains such citizenship. The policy of Contracting States regarding the nationality of the child should be guided by the overriding importance of avoiding a situation in which an adopted child is stateless. ${ }^{77}$

Recommendation No. 17 was reaffirmed by the June 2010 Meeting of the Special Commission, which added that:

20. Central Authorities should co-operate in the completion of any formalities necessary for the acquisition by the child of the nationality, where appropriate, either of the receiving State or of an adoptive parent.

21. The question of whether nationality will be granted to the child may, where appropriate, be a relevant factor when a State of origin is considering co-operation with a particular receiving State. ${ }^{78}$

As a result, because of the adoption, an adopted child should acquire ex lege the nationality of the adoptive parents without any additional conditions or procedures. ${ }^{79}$ However, domestic nationality law may provide for restrictions similar

\footnotetext{
${ }^{76}$ Please note the tension between Art. 11(1) ECAC and Art. 12 ECAC which only prescribes a facilitation of the acquisition of nationality of the adopters which is far from granting adopted children the same rights as other children of the adopter.

${ }^{77}$ Conclusions and Recommendations of the Second Meeting of the Special Commission on the Practical Operation of the Hague Convention of 29 May 1993 on Protection of Children and Co-Operation in Respect of Intercountry Adoption (17-23 September 2005).

${ }^{78}$ Special Commission on the practical operation of the Hague Convention of 29 May 1993 on Protection of Children and Co-operation in Respect of Intercountry Adoption (17-25 June 2010), Conclusions and Recommendations Adopted by the Special Commission.

${ }^{79}$ See Para. 36 and 37 of the Explanatory Memorandum on Rec. 2009/13.
} 
to those applicable to biological children in cases of birth abroad, if these restrictions do not lead to statelessness. It should be irrelevant whether the adoption decree was issued in the State involved or abroad. In the latter case, the mere fact of the recognition of the foreign adoption in the State of the nationality of the adoptive parents should have nationality consequences. This principle should apply to all full adoptions, i.e. where the legal relationship between the child and his or her father, mother and family of origin is terminated and replaced by the legal relationship with the adopter(s).

In light of these considerations Recommendation 2009/13 of the Committee of Ministers of the Council of Europe recommends to the Member States of the Council of Europe

"13. subject the granting of their nationality to children adopted by a national to no other exceptions than those generally applicable to the acquisition of their nationality by right of blood, if as a consequence of the adoption the family relationship between the child and the parent(s) of origin is completely replaced by the family relationship between the child and the adopter(s)"

If a State provides for other forms of adoption having more limited effects (for instance a so-called simple adoption, which does not completely replace the original family relationship by a legal family relationship with the adopter(s)), a State may also provide for the acquisition of its nationality ex lege, but should at least facilitate the acquisition of its nationality. The latter rule should also apply if a foreign simple adoption is recognised as a simple adoption, e.g. as prescribed by the rules of the 1993 Hague Adoption Convention. ${ }^{80}$

Principle 14 of Rec. 2009/ 13 therefore recommends that States:

"facilitate the acquisition of their nationality by children adopted by a national in the case of an adoption in which the family relationship between the child and the parent(s) of origin is not completely replaced by the family relationship between the child and the adopter(s)".

A very special problem arises if a foreign child resides for a considerable period of time in the State of residence of a prospective adopting parent with a view to being adopted and the adoption is not finalised (i.e. not granted or not completed). Such a child should be entitled to apply for the acquisition of the nationality of the State of residence.$^{81}$ First, due to the fact that the State allowed the child to enter its territory in view of a future adoption, this State has taken a special responsibility for the future of this particularly vulnerable child. Second, as a result of the child's residence on this territory he or she acquires a genuine link

\footnotetext{
${ }^{80}$ See Art. 23-27 HAC.

${ }^{81}$ See Para. 40 of the Explanatory Memorandum on Rec. 2009/13.
} 
with the State involved, whereas insufficient ties could be developed with her or his country of origin. Of course, in all cases where the adoption was not granted or the procedure is not completed, the highest priority should be to find another (adoption) family for the child.

In light of these considerations principle 16 of Recommendation 2009/13 therefore underpins that States should:

"provide that foreign children lawfully residing on their territory with a view to adoption have the right to file applications for the acquisition of their nationality if the adoption is not finalised. States should not in this case require a period of more than five years of habitual residence on their territory".

\subsubsection{Choices to be made}

In light of the standards described in the previous paragraph, States should regulate the acquisition of nationality by children adopted by a national in a way equivalent to the acquisition of nationality iure filiationis. In that light, States could decide to apply in principle the general rules for acquisition iure filiationis also in case of adoption of a minor by a national.

As with the acquisition of nationality iure filiationis, a State has to regulate the consequences of an adoption of a child after (s)he has attained the age of majority. Some States provide for a facilitated naturalisation in such $\operatorname{cases}^{82}$ or by granting a possibility of acquisition of nationality by the exercise of an option right. $^{83}$

A very special question is whether a State which limits the acquisition of nationality in case of birth abroad ${ }^{84}$ should do this also in case of adopted children born abroad. As such, the acquisition of nationality by adoption is an acquisition iure filiationis. As pointed out above, this could justify not regulating adoption as a separate way of acquisition of nationality but as a way to acquire the nationality by ius filiationis. However, precisely in respect of the acquisition of nationality by adopted children born abroad a special regulation may be appropriate. The justification for posing a limitation of the acquisition of nationality iure filiationis in case of birth abroad is the assumption that the child involved will not develop strong ties with the country of nationality of the parent. In case of intercountry adoption, this is really different: the child will usually leave the country of origin and will grow up in another country, in most cases in the country of nationality of the adopting parent(s). This makes a positive differential treatment of acquisition of nationality by adoption desirable in those States where the intergenerational transfer of nationality is limited in case of birth

\footnotetext{
${ }^{82}$ Art. 8(2) RwNed. Regrettably, bill 33852 (R2023) pending in parliament since 28 January 2014 proposes to delete this facilitation.

${ }^{83}$ Art. 19(2) Cc esp.

${ }^{84}$ See above para. 2.1.3.
} 
abroad. ${ }^{85}$ The choice to be made by a legislator of a country which provides for a limitation of acquisition of nationality iure filiationis in case of birth abroad, is whether in case of intercountry adoption no limitation should apply or whether the adopting parent will be granted the right to make a declaration of option of registration in favour of the acquisition of nationality by adoption.

\subsubsection{Related grounds for acquisition and loss and related general issues}

As mentioned above, ${ }^{86}$ a very much related ground for acquisition of nationality is the acquisition iure filiationis. In fact, the acquisition by adoption is itself an acquisition iure filiationis.

A difficult situation arises if revocation or annulment of an adoption takes place. ${ }^{87}$ According to Article 7(1)(f) ECN, this may not cause loss of nationality if the adopted child has already reached the age of majority. Furthermore, revocation or annulment shall never result in loss of nationality if statelessness would be the consequence.$^{88}$ Recommendation 2009/13, however, goes further by providing in principle 15 that revocation or annulment of the adoption should not lead to a loss of nationality of a State acquired by the adoption if the child is already lawfully and habitually resident in that State for a period of more than five years. This principle - which is inspired by the overriding principle of the best interests of the child and the protection of legitimate expectations - reads as follows:

"15. provide that revocation or annulment of an adoption will not cause the permanent loss of the nationality acquired by the adoption, if the child is lawfully and habitually resident on their territory for a period of more than five years"

The Explanatory Memorandum to Recommendation 2009/13 ${ }^{89}$ mentions that in order to fulfil this principle, a State could provide that after a certain period of residence no loss occurs as a consequence of the revocation or annulment. However, it would also be in line with the principle if the annulment or revocation as such causes the loss of nationality but that the State concerned avoids a permanent loss of this nationality by providing for the immediate recovery of that nationality at the moment of loss, e.g. by a naturalisation already prepared beforehand.

Another related ground for loss is loss due to loss of the family relationship which was the basis for the acquisition of nationality. ${ }^{90}$

\footnotetext{
${ }^{85}$ In this light I am not happy with the negative differential treatment of adopted children in the decision of the Netherlands Council of State (Raad van State) 4 November 2015, ECLI:NL:RVS:2015:3361. See my critical case note in Jurisprudentie Vreemdelingenrecht 2016, no. 4, p. 12-19.

${ }^{86}$ See para. 2.1.4.

${ }^{87}$ See para. 39 of the Explanatory Memorandum on Rec. 2009/13.

${ }^{88}$ So also Art. 5 CRS 1961. See in the Eudo-citizenship database mode L13b.

${ }^{89}$ See again para. 39 of the Explanatory Memorandum on Rec. 2009/13.

${ }^{90}$ See Eudo-citizenship database mode L13a and hereinafter para. 2.5
} 
Due to the fact that adoption creates a parentage tie between the adopted child and the adopting parent(s), most States provide that the birth certificate of the adopted child will be amended. After the adoption, an extract from this birth certificate will indicate the adopting parents as parents without mentioning the fact of the adoption. If the rules on the acquisition of nationality by adoption are more narrow than the general rules on acquisition of nationality iure filiationis, this may cause difficulties if the authorities discover the fact of the adoption after having treated the child already for a considerable period as a national iure filiationis. There is then need for protection of legitimate expectations. ${ }^{91}$

\subsubsection{An assessment of case 2}

It is highly problematic not to provide for the acquisition of nationality of an adoptive parent by the adopted child under conditions identical to those applicable to a normal ius sanguinis acquisition when the parentage tie established by an adoption realised abroad is recognised. As recommended by the Committee of Ministers of the Council of Europe, the (recognition of the) creation of the legal parentage tie between the adopted child and the adopting parent(s) should have the same nationality consequences as in case of the birth of a child to those parents. As the Special Commission on the practical operation of the Hague Adoption Convention pointed out, the nationality position of the adopted child should not rely on any action of the adopting parents. This is all the more important because often these parents expect that the creation of the legal parentage ties between them and the child already implies the applicability of the rules on acquisition of nationality iure sanguinis of their State.

Case 2 also illustrates that a State which wants to bring the nationality rules in accordance with international standards should pay appropriate attention to transitory provisions. The Netherlands lacked to do so, both in 1998 and in 2006. This is particularly problematic because Netherlands nationality law does not honour legitimate expectations. This lack of protection of legitimate expectations leads to situations which amount to arbitrary deprivation of nationality.

${ }^{91}$ See hereinafter para. 2.7. 


\subsection{Loss of nationality due to residence abroad}

\subsubsection{Case 3 Loss of nationality during pending nationality proceedings}

Eveline and Frederique were born in Ghana respectively in 1978 and 1980 as children out of wedlock of a Ghanaian mother. In 1983 the mother married Govert Grutters, a man holding Netherlands nationality. In the same year she acquired Netherlands nationality by lodging a declaration of option.92 In 1985 the principle of equal treatment of men and women was introduced in Netherlands nationality law. Since then men and women can both transmit their Netherlands nationality to their children. Based on a transitory provision93 the mother lodged a declaration of option in favour of her daughters, who acquired by that declaration Netherlands nationality in 1985. Since around 1995 Eveline and Frederique wanted to travel to the Netherlands and apply for Netherlands passports. However, their applications were repeatedly rejected because they cannot submit the copies of their birth certificates which were used at the occasion of lodging the option declaration in 1985. For that reason the authorities have doubts whether they are really Eveline and Frederique in favour of whom the option declaration was lodged in 1985. In 2012 they start proceedings in the Court of The Hague in order to get a court decision confirming their possession of Netherlands nationality. In November 2013 the Immigration and Naturalisation Department (hereinafter IND) as competent authority recognised that Eveline and Frederique had acquired Netherlands nationality by the declaration of option and also that the applicants are in fact the girls involved. However, the IND stated that they had lost Netherlands nationality on 1 April 2013 by residing ten years outside the Kingdom of the Netherlands and the European Union because they had not received before that day a Netherlands passport or a certificate of possession of Netherlands nationality. A letter sent to the lawyer of the girls by the IND with as topic "evidence of naturalisation" did not qualify as a certificate of possession of Netherlands nationality. Moreover, starting proceedings in the Court of The Hague in order to receive a judicial confirmation of the possession of Netherlands nationality also did not prevent the loss of nationality. ${ }^{94}$

\subsubsection{Relevant international standards}

The idea that nationality should express a genuine link between a person and a State and that the loss of this link should also imply the loss of this status is expressed most clearly in provisions in nationality laws that provide for the loss of nationality for those citizens who permanently reside in another State. ${ }^{95}$

\footnotetext{
${ }_{92}$ Based on Art. 8 Wet op het Nederlanderschap en het ingezetenschap as in force until 1 January 1985.

${ }^{93}$ Art. 27 RwNed as operative from 1985 until 1988.

${ }^{94}$ The case description is based on the facts of the decision of the Supreme Court of the Netherlands (Hoge Raad) of 27 March 2015, ECLI:NL:HR:2015:761.

${ }^{95}$ De Groot 1989, 290-295; Vink/ De Groot 2010a; SG UN 2013, A/HRC/25/28. para. 18.
} 
Art. 7(1)(e) ECN explicitly allows for the loss of nationality because of a "lack of a genuine link between the State Party and a national habitually residing abroad". However, this ground for loss may not cause statelessness.

The explanatory report on the $\mathrm{ECN}^{96}$ underscores that:

"Possible evidence of the lack of a genuine link may in particular be the omission of one of the following steps taken with the competent authorities of the State Party concerned:

(i) registration;

(ii) application for identity or travel documents

(iii) declaration expressing the desire to conserve the nationality of the State Party."

The explanatory report ${ }^{97}$ also stresses that:

"[i]t is presumed that the state concerned will have taken all reasonable measures to ensure that this information is communicated to the persons concerned."

The right to an administrative or judicial review (Art. $12 \mathrm{ECN}$ ) is in the explanatory report expressly underlined with regard to this ground for loss. ${ }^{98}$ Arguably, this implies that a judge could come to the conclusion that despite the formal criteria for the loss of citizenship having been fulfilled, there still is a genuine link between the respective State and the individual concerned. ${ }^{99}$

Whereas the 1961 Convention originally accepted in Art. 7(3) that loss because of permanent residence abroad may, under exceptional circumstances, cause statelessness, the 2013 Tunis Conclusions on the interpretation of the Art. 5-9 CRS 1961 underscore that a very restrictive interpretation of Art. 7(3) CRS in light of a proportionality test is necessary:

"There was a consensus that loss of nationality under Article 7(3) will generally not be permissible if the individual concerned is left stateless. Increasing international migration means that the character of the bond between the individual and the State has considerably evolved and often involves only sporadic contact with the authorities and visits to the country of nationality. As a result, the objective of ensuring strong links between the individual and the State is less relevant than at the time of drafting of the 1961 Convention. Consequently, such provisions have become increasingly rare in nationality laws. In most cases,

\footnotetext{
${ }^{96}$ Explanatory report on the ECN, para. 71.

${ }^{97}$ Explanatory report on the ECN, para. 70.

${ }^{98}$ Explanatory report on the ECN, para. 72.

${ }^{99}$ See also De Groot 2015; regrettably different: Supreme Court of the Netherlands (Hoge Raad) 27 March 2015, ECLI:NL:HR:2015:761, Jurisprudentie Vreemdelingenrecht 2015, nr. 259, p. 1215-1224

(with critical comment De Groot). Compare also Jessurun d'Oliveira 2016.
} 
loss of nationality resulting in statelessness will not meet the proportionality test because the impact on the individual far outweighs the objective sought by the State.

The 1961 Convention indicates, moreover, that a naturalised person may not lose her or his citizenship based on this ground on account of residence abroad for a period of less than seven consecutive years (Article 7(4)). The European Convention does not specify such a minimum period of residence abroad and also does not restrict this ground to naturalised persons."

In respect of the last sentence of this citation from the Tunis Conclusions, it has to be stressed that the ECN is generally against a different treatment of nationals by birth and nationals who acquired their nationality later in their life. ${ }^{100}$

Regarding the loss of nationality due to residence abroad Resolution III, adopted during the final conference where the CRS 1961 was signed, has to be mentioned:

"The Conference recommends Contracting States making the retention of nationality by their nationals abroad subject to a declaration or registration to take all possible steps to ensure that such persons are informed in time of the formalities and time limits to be observed if they are to retain their nationality." 101

In light of the standards just described - and with due regard to the right of free movement of European citizens within the European Union - the ILEC Guidelines $2015^{102}$ conclude in respect of this ground for loss inter alia:

"Member States may only consider that residence abroad may lead to loss of their nationality provided the following principles are observed:

a) Loss of nationality on the grounds of residence abroad should never cause statelessness;

b) Loss of nationality should not apply in case of residence in another Member State of the European Union;

c) Loss of nationality should not apply only to naturalised citizens;

d) All relevant circumstances should be taken into account, in particular all indications of existing links with the state involved;

e) Member States have an obligation to inform the person concerned explicitly and individually about the steps to be taken in order to avoid loss of nationality due to residence abroad. Member States should use a 'deprivation' construction rather than an 'automatic loss' approach.

\footnotetext{
${ }^{100}$ Art. 5(2) ECN.

${ }^{101}$ Compare the explanatory report on the ECN, para. 72, already cited above.

${ }^{102}$ Para. IV.2.
} 
f) If loss of nationality due to residence abroad can be prevented by a declaration, the application for a passport or identity card should suffice; if such declaration should be made within a certain period, this period should be longer than the period of validity of a passport or identity card;

g) In the context of checking the proportionality of a deprivation decision, it is appropriate to distinguish between the first generation born abroad and further generations born abroad."

\subsubsection{Choices to be made}

In light of the standards described above in para. 2.3.1, a State which wants to provide for loss of nationality in cases of permanent residence abroad has to do so in a way that allows taking into account all relevant circumstances in the context of a proportionality test. Due to the necessary assessment of the proportionality, it is definitely wise to prefer the construction of a deprivation of nationality to an ex lege loss. ${ }^{103}$

Furthermore, it has to be regulated how the nationals involved will be informed in time about the formalities and time limits to be observed if they want to retain their nationality. This should include confirmation of the number of years of residence abroad the loss may occur and also whether the ground for loss can only operate in case of residence abroad during the relevant number of years counted from the moment of attaining the age of majority or also after this number of years of residence abroad later in life. A disadvantage of this choice also applying this ground for loss after residence abroad at a later moment in life ${ }^{104}$ is that it may cause the loss of nationality of older nationals who are no longer able to care for their own interests and are dependent on actions of relatives or friends. Moreover, a State has to realise that the application of this ground for loss at a late moment of life of a person may have consequences for the right to impose succession taxes after the death of the person involved. ${ }^{105}$

\subsubsection{Related grounds for acquisition and loss and related general issues}

A related ground for acquisition is limitation of acquisition in case of birth abroad $^{106}$ (see above para. 2.1.2). Another related ground for acquisition is the recovery of nationality (reacquisition of nationality by a former national) ${ }^{107}$ : if a former national who lost the nationality by residence abroad may simply reacquire this nationality by registration, this may influence the result of the application of the proportionality test. ${ }^{108}$

\footnotetext{
${ }^{103}$ De Groot 2015; Jessurun d'Oliveira 2016.

${ }^{104}$ As provided by e.g. Art. 15(1)(c) RwNed. Compare Eudo-citizenship database mode L02.

${ }^{105}$ Compare e.g. for the Netherlands Art. 3 (1) Successiewet.

${ }^{106}$ Eudo-citizenship database mode A01b.

${ }^{107}$ Eudo-citizenship database mode A16.

${ }^{108}$ Compare Sect. 13(1) BNA, which allows a former national who lost his citizenship by declaration of renunciation to reacquire British citizenship by registration.
} 
For all grounds of loss procedural issues are of paramount importance. No ground for loss should have arbitrary effects. The proportionality of the loss of nationality should be established beyond any reasonable doubt. ${ }^{109}$

\subsubsection{An assessment of case 3}

In light of the international standards described above, all circumstances have to be taken into account in order to assess whether a genuine link still exists between a national residing abroad and the State of nationality. For that reason the construction of a possible deprivation of nationality has to be preferred to an ex lege loss of nationality due to permanent residence abroad. It would be welcomed if the legislator of the Netherlands would change the current ground for loss accordingly. Moreover, the list of documents which can prevent the loss of nationality due to residence abroad does not include some acts or facts which demonstrate beyond any doubt that the person involved wants to continue to be a Netherlands national. For example, the application for issuing a Netherlands passport or a certificate of the possession of Netherlands nationality, respectively initiating court proceeding in order to get a judicial confirmation of the possession of Netherlands nationality are lacking. This type of acts or facts should be inserted in the list of documents which prevent the loss of nationality. A judge confronted with case 3 could also decide that the list of documents is not exhaustive. Not doing so and instead concluding that Netherlands nationality is lost -as the Netherlands Supreme Court did- could be qualified as arbitrary deprivation of nationality. ${ }^{110}$

\footnotetext{
${ }^{109}$ See hereinafter para. 2.6.

${ }^{110}$ See my very critical case note under the decision of the Supreme Court of 27 March 2015 in Jurisprudentie Vreemdelingenrecht 2015, no. 259, p. 1215-1224.
} 


\subsection{Loss of nationality due to activities seriously prejudicial to the vital interests of the State}

\subsubsection{Case 4 Deprivation of nationality of terrorist fighters}

In December 2015 the Netherlands Minister of Security and Justice sent a bill to parliament proposing to introduce the possibility of deprivation of nationality in case of participation in a terrorist organisation. ${ }^{111}$ The Minister would be allowed to take such a deprivation decision on the basis of information (i.a. of the secret services) on participation in a terrorist organisation. The deprivation may not cause statelessness. For that reason this measure can only be taken if the person is a dual or multiple national. The goal of the proposed measure is the protection of the security of the Netherlands against a terrorist threat. The explanatory memorandum accompanying the bill stresses that the proposed possibility of deprivation is no sanction under criminal law, but an administrative measure to protect public safety.

The proposed measure would be in addition to the possibility of deprivation of nationality of a person who, since 2010, was sentenced because of having committed a crime seriously prejudicial to the vital interest of the State and punishable with imprisonment of 8 years or more. That possibility is enshrined in art. 14 (2) Netherlands Nationality Act (Rijkswet op het Nederlanderschap), which refers to the relevant articles of the Criminal Code. Art. 14(2) was recently ${ }^{112}$ amended so as to include also the delict of Art. 134a Criminal Code, dealing with several kinds of preparatory acts for committing a terrorist crime. ${ }^{113}$

To determine the scope of application of the proposed possibility to deprive someone of his or her nationality, it is of course highly relevant which organisations would be classified as having a terrorist aim. The bill provides that the Minister will publish a list of relevant organisations after consultation of Council of Ministers of the Kingdom. The explanatory memorandum indicates that the PKK, FARC and Tamil Tigers will not be put on this list, whereas Islamic State and Al-Qaida will.

The bill explicitly regulates the possibility of judicial review by the Court of The Hague or if the person involved is resident in the Caribbean part of the Kingdom of the Netherlands the Court of Aruba, respectively Curaçao or St Maarten. From a decision of the Court of the Hague appeal is possible to the Council of State (Raad van State) or in the Carribean part of the Kingdom the possibility of appeal to the Common Court of Justice (Gemeenschappelijk Hof van Justitie) will be giv-

\footnotetext{
${ }^{111}$ Bill 34356 (R2064).

${ }^{112}$ Kingdom Act of 5 March 2016, Staatsblad 2016, 121, in force on 31 March 2016.

113 “[...] zich of een ander opzettelijk gelegenheid, middelen of inlichtingen verschaft of tracht te verschaffen tot het plegen van een terroristisch misdrijf dan wel een misdrijf ter voorbereiding of vergemakkelijking van een terroristisch misdrijf, dan wel zich kennis of vaardigheden daartoe verwerft of een ander bijbrengt".
} 
en. However, challenging the deprivation decision taken by the Minister will not have any suspensive effect, as the deprivation works immediately. The overall goal of the measure is to apply the power of deprivation to nationals residing abroad in order to hinder their return to the Netherlands, due to the fact that the persons involved are deemed to be a threat to the security of the Netherlands.

\subsubsection{Relevant international standards}

Several States maintain a general ground for loss of nationality due to disloyalty, treason, violation of 'duties as a national', or similar behaviour that is considered to be seriously prejudicial to the interests of the State involved. ${ }^{114}$ Art. 7(1) (d) ECN mentions conduct in a manner seriously prejudicial to the vital interests of the State Party as a separate ground for loss. The wording of that provision is drawn from Article 8(3)(a)(ii) of the 1961 CRS. It is remarkable that the related provisions from Article 8(3)(a)(i) (in disregard of an express prohibition rendering services to or receiving emoluments from another State) and 8(3)(b) CRS (taking an oath or making a formal declaration of allegiance to another State or giving definite evidence of his determination to repudiate his allegiance with the State involved) are not included in the ECN. For that reason, it should be concluded that these acts do not constitute behaviour seriously prejudicial to the vital interests of a State under the ECN. The explanatory report on the ECN is silent on this point.

However, it stresses that the conduct involved includes notably treason and other activities directed against the vital interests of the State concerned, for example work for a foreign secret service, but does not include criminal offences of a general nature, however serious they may be. ${ }^{115}$

The ECN does not allow this ground for loss to cause statelessness. For that reason only dual or multiple nationals are at risk of being deprived of their nationality. ${ }^{116}$ Art. 8(3) CRS 1961 stipulates that conduct seriously prejudicial to the vital interests of the State can exceptionally constitute a ground for deprivation of nationality with statelessness as consequence, but only if it is an existing ground for deprivation in the internal law of the State concerned, which, at the time of signature, ratification or accession, the State specifies it will retain. ${ }^{117}$ Art. 8(4) CRS 1961 stipulates a fair hearing by an independent body, whereas also the ECN prescribes to provide reasons in writing and access to a court. ${ }^{118}$

It has to be mentioned that provisions dealing with this ground of loss are often problematic with regard to the unequal treatment of citizens, for example, if only naturalised citizens - but not 'natural born' citizens - can be deprived of

\footnotetext{
${ }^{114}$ De Groot 1989, 301, 295-298; De Groot/ Vink 2014, para. 5 and Table 3.4.

${ }^{115}$ Explanatory Report on the ECN, para. 87.

${ }^{116}$ See De Groot/Vink 2014, para. 5 and the fifth column of Table 34.

${ }^{117} 10$ of the 65 Contracting States made such a declaration of retention.

${ }^{118}$ See on these procedural safeguards hereinafter para. 2.6.
} 
nationality. Such an exclusive application to naturalised citizens is in violation of Art. 5(2) ECN. But also if States apply these loss regulations only to dual citizens, there is a serious problem if the nationals involved are not able to renounce their other nationality and are for that reason dual nationals against their will. Countries which do not allow renunciation of nationality are - next a number of States in Latin America ${ }^{119}$ and Oceania ${ }^{120}$ - mainly Arab States. ${ }^{121}$ The question then arises, whether such regulations of loss are discriminatory for dual nationals with roots in that part of the world.

In light of the standards and the problems just mentioned the ILEC Guidelines 2015 recommend in respect of this ground for loss ${ }^{122}$ :

"Member States may only consider that undesirable behaviour may lead to loss of their nationality provided the following principles are observed:

a) Loss of nationality due to undesirable behaviour (e.g. acts seriously prejudicial to the vital interests of the State or foreign military service) should never cause statelessness;

b) Due to the paramount importance of the proportionality principle, loss of nationality due to undesirable behaviour should never occur automatically, but always by deprivation through means of an explicit decision by competent authorities;

c) The unacceptable character of the undesirable behaviour of the person involved should be proven beyond any reasonable doubt. Such behaviour should constitute a crime and a criminal court should have imposed a sanction;",

A strong caveat regarding deprivation of nationality due to activities seriously prejudicial to the vital interests of the State can also be found in a report sent by the Secretary-General of the United Nations to the Human Rights Council. The report observes that many provisions dealing with this ground for deprivation are rather general in scope, which makes this ground for loss a potential source of legal insecurity. Furthermore, depending on the exact formulation of these grounds for loss, they can constitute a danger for human rights norms, in particular the freedom of speech. ${ }^{123}$ The danger of too open formulas is also recognised by several countries that do not apply this ground for loss, based on historical experiences with authoritarian regimes. Their Constitutions contain explicit provisions that citizens should not be deprived of their citizenship because of their behaviour, often with the exception of deprivation of nationality

\footnotetext{
${ }^{119}$ Argentina, Costa Rica, Cuba, Dominican Republic, Ecuador, Honduras, Mexico, Nicaragua and Uruguay. However, some of these countries allow for loss of nationality of some categories of nationals, in particular for naturalised persons. See Bijlage 1 belonging to the comment on Art. 9 in the Handleiding voor de toepassing van de Rijkswet op het Nederlanderschap and compare the information on Eudo-citizenship database mode L01.

${ }^{120}$ Nauru and Tonga. See the Bijlage 1, mentioned in the previous footnote.

${ }^{121}$ Algeria, Bangladesh, Iran, Libya, Morocco, Pakistan, Syria, Tunisia and Yemen. See Bijlage 1, as mentioned above.

${ }^{122}$ ILEC Guidelines, IV.3. Compare also the Tunis Conclusions, para. 15-24.

${ }^{123}$ SG UN 2013, A/HRC/25/28, para. 13.
} 
due to fraud committed during the naturalisation procedure. ${ }^{124}$ Nevertheless, we find this ground for loss in around half of the States. ${ }^{125}$

\subsubsection{Choices to be made}

A State wishing to provide for this ground of loss should realise that the deprivation of nationality may cause problems for international criminal jurisdiction of courts in respect of acts committed by the person whose nationality is taken away. ${ }^{126}$ The deprivation of nationality may also constitute an impediment as to the enforcement of criminal court sentences against the person concerned. This is highly problematic in light of the obligation to prosecute effectively international crimes such as terrorist acts. ${ }^{127}$

If the deprivation of nationality happens in order to be able to expel the person concerned, this may also be questionable because of the fact that deprivation of nationality "for the sole purpose of expelling him or her" is not allowed by the 2014 ILC Draft Articles on the expulsion of aliens. ${ }^{128}$

Deprivation of nationality due to behaviour seriously prejudicial to the vital interests of the State may also cause the export of risks. Persons deprived of their nationality will likely permanently join the "international army of terrorists". If they still possess the nationality of another State, they may go to the country of that (other) nationality which could result in a heightened political and security risk in that country. This is highly problematic in light of the international solidarity which is essential in the war against terrorism.

Moreover, if only dual nationals can be deprived of their citizenship on this ground, due to the fact that no statelessness should be the consequence, this may cause a race between the States concerned in order to be quicker than the other State in respect of this type of deprivation procedures.

There may also be a tension with the "ne bis in idem" principle as applicable in criminal law: ${ }^{129}$ the deprivation of nationality may be classified as a second sanction on the basis of the same facts.

Given the fact that several persons engaged in terrorist activities in particular in Iraq and Syria went to these countries with their families, a State which deprives a national of her or his nationality should also realise that this deprivation

\footnotetext{
${ }^{124}$ See for example German Basic Law: Art. 16(1), Polish Constitution: Art. 34(2)).

${ }^{125}$ Manby 2015, 175, 176; Vonk 2014; database Eudocitizenship mode L07 (disloyalty and treason) .

${ }^{126}$ Compare the bad experiences in the Netherlands with the prosecution of former Netherlands nationals who lost their nationality by military service in the German army during WW II. See De Groot/ Vonk 2015.

${ }^{127}$ Goodwin-Gill 2014, 13-15.

${ }^{128}$ Art. 8 of the 2014 ILC Draft Articles on the expulsion of aliens: http://legal.un.org/ilc/texts/instruments/english/ commentaries/9_12_2014.pdf; see also Goodwin-Gill 2014, 11; Lambert 2015, 15.

${ }^{129}$ Compare the decision of the Supreme Court of the Netherlands (Hoge Raad) 3 March 2015, ECLI:NL:HR:2015:434; NJ 2015, 558.
} 
should -according to the international standards - not have consequences for the nationality of her or his children. The children born before the deprivation became effective will still continue to be nationals. They may ask for diplomatic or consular protection and ask for travel documents which enable them to travel to their country of nationality.

For European States deprivation of nationality may also violate the right to respect private and family life under Art. 8 ECHR. ${ }^{130}$

\subsubsection{Related grounds for acquisition and loss and related general issues}

Related grounds for loss are foreign military service ${ }^{131}$ and foreign state service. ${ }^{132}$ Whereas the $1997 \mathrm{ECN}$ allows States to provide for loss of nationality in case of foreign military service, this is not the case for foreign state service. In extreme cases the foreign military or state service may constitute behaviour seriously prejudicial against the vital interests of the State.

For all grounds of loss procedural issues are of paramount importance. No ground for loss should have arbitrary effects. The proportionality of the loss of nationality should be established beyond any reasonable doubt. See hereinafter para. 2.6

\subsubsection{An assessment of case $4^{133}$}

First of all, the goal of the proposal made by the bill sent to the parliament of the Netherlands in December 2015 is unclear. Is it a preventive measure or a reaction on behaviour seriously prejudicial to the vital interests of the State? The deprivation of nationality as a preventive measure evidently violates the international standards!!! Deprivation based on behaviour seriously prejudicial to the vital interest of the State is allowed, although the nationality legislation of the Netherlands already provides for this ground for deprivation in Art. 14 (2) RwNed.

Second, there is a huge risk of discrimination of Netherlands nationals with dual/ multiple nationality, in particular of persons who are not able to renounce their other nationality. The proposed possible deprivation will be in particular a threat for Netherlands nationals with roots in the Arab world.

Third, ISIS and Al Qaida will be put on the black list of terrorist organisations, but FARC, PKK and Tamil Tigers will not. The reason for this is that the latter organisations do not pose a threat to the security of the Netherlands. This may be true, but is this not at least an appearance of discrimination?

\footnotetext{
${ }^{130}$ Goodwin-Gill 2014; Lambert 2015, 15.

${ }^{131}$ Eudo-citizenship database mode L03.

${ }^{132}$ Eudo-citizenship database mode L04.

${ }^{133}$ See also the discussion on EUDO CITIZENSHIP on "The Return of Banishment: Do the New Denationalisation Policies Weaken Citizenship?", available on http://eudo-citizenship.eu/commentaries/citizenship-forum/1268the-return-of-banishment-do-the-new-denationalisation-policies-weaken-citizenship. See also SG UN 2013, A/ HRC/25/28, para. 13; De Groot/ Vonk 2015 and 2016; Wautelet 2015 and 2016.
} 
Fourth, the regulation of the judicial control is rather weak. Why was it not proposed to put the deprivation directly in de hands of the courts? Why should there be different courts of last resort for the Netherlands, respectively the Caribbean part of the Kingdom? Why is a provision on the suspensive effect of the appeal lacking? Why is there no previous criminal procedure prescribed? Why is it not regulated how to deal precisely with information submitted by the secrete services? And is it allowed to refuse the person involved to return to the Netherlands, if he wants to be present during the court procedure assessing the deprivation of his Netherlands nationality?

Fifth, deprivation of nationality weakens the international criminal jurisdiction of the courts in the Netherlands.

Sixth, loss of nationality due to behaviour seriously prejudicial to the vital interest of the State may not be extended to minor children of the person whose nationality is lost by the act of deprivation. These minors will therefore continue to be nationals and have the right to return to the Netherlands. Netherlands embassies and consulates can also be confronted with the request of these children to give diplomatic and consular protection.

To sum up, many arguments can be advanced against the proposal. Special attention has to be paid to the risk of discrimination and the very weak procedural safeguards. Non-discrimination and strong procedural safeguards are core values of our society. They should not be sacrificed because of the threat of terrorist attacks. 


\subsection{Loss of nationality due to loss of family relationship}

\subsubsection{Case 5 A successful denial of paternity}

Hans Helders, sixteen years old, was born in Escondido (California, United States) as the son of the American Jane Johnson and her husband Karel Koenders. He acquired both American citizenship and Netherlands nationality. Hans grew up in California, but came to Europe two years ago because his father got a very good job offer in Berlin (Germany). Hans is attending the international school in Berlin, where he is doing very well.

However, he has recently experienced tremendous difficulties to concentrate on his studies as a result of the disturbing news he received about his parents. Three months ago, he received a message from his father from which he learned that Karel is in fact not his biological father. It seems that his mother has conceded that Hans was fathered by Leonard Lampe, an American living in Ohio. Karel is extremely upset about this information and wanted to have Hans' collaboration for a DNA-test. Having done so, Hans recently received a copy of the DNA-report, which comes to the conclusion that with a certainty of 99,999\% Karel is not his biological father. Karel announced that he now will start legal proceedings in order to challenge his legal paternity of Hans.

Apart from the psychological stress caused by these messages, Hans is also extremely worried about the legal consequences of a successful denial of paternity. If he is not the son of a Netherlands father anymore, will he still be a Netherlands national and therefore a European citizen?

With the assistance of a good friend, he asks information at the embassy of the Netherlands in Berlin. To his huge disappointment he receives the answer that his Netherlands nationality and consequently his European citizenship will be lost in case the successful denial of paternity procedure will become final before he reaches the age of eighteen years. ${ }^{134}$

\subsubsection{Relevant international standards}

Given that nationality is often automatically acquired because a parent is a national (iure filiationis), this acquisition is seriously undermined if it becomes evident that the assumed family relationship never existed, for example in case of an ex tunc effect of a judicial confirmation following a denial of maternity or paternity, ${ }^{135}$ if the family relationship ends because of annulment or revocation of adoption, or if it ends because of adoption. ${ }^{136}$ Art. 7(1)(f) and 7(1)(g) ECN and Art. 5 of the 1961 CRS allow in those cases to provide for the loss, except if statelessness would be caused. Art. 7 ECN stipulates also that this ground

\footnotetext{
${ }^{134}$ The case description is based on an e-mail I received from the lawyer of the son and his mother.

${ }^{135}$ E.g. in case of a successful challenge of the presumption "pater est quem matrimonium demonstrat."

${ }^{136}$ De Groot 1989, 301-303.
} 
for loss should not apply if the person involved has already reached the age of majority.

It is remarkable that only a few States regulate this ground for loss expressly. ${ }^{137}$ However, it is even more striking that in countries that do not mention this ground for loss specifically in their legislation, it is not always clear whether this implies that no such ground for loss exists. ${ }^{138}$ This is highly problematic in light of the fact that arbitrary deprivation of nationality is forbidden. ${ }^{139}$ The lack of a clear legal basis for a certain mode of loss of nationality implies arbitrariness: Nulla perditio sine praevia lege. ${ }^{140}$

Recommendation 2009/13 of the Committee of Ministers of the Council of Europe on the position of children in nationality law is also relevant in case of loss of the family relationship which was the basis for the acquisition of nationality. Member States are recommended to:

" provide that children who were treated in good faith as their nationals for a specific period of time should not be declared as not having acquired their nationality"

The Explanatory Memorandum on this principle underline:

"43. Article 7, paragraph 1 (f) of the ECN provides for the loss of nationality in cases of non-fulfilment of the preconditions, which led to the acquisition of the nationality ex lege, during the minority of the person involved. Several different situations are covered by this provision: firstly, the provision applies to situations where a child has acquired a nationality as a foundling and later, after discovery of his or her parent(s), appears to have the nationality of the parent(s) jure sanguinis. Secondly, the rule also applies in the event that a child has acquired the nationality of his or her state of birth because he or she would have otherwise been stateless, but further evidence shows that he or she had also acquired another nationality jure sanguinis. In both cases, the loss involved is a correction of a default jus soli acquisition.

44. But the loss can also be the consequence of a retroactive (ex tunc) loss of the family relationship on which the acquisition of nationality jure sanguinis was based, for example because of a successful denial of paternity, annulment of a recognition of paternity or an ex tunc annulment of an adoption.

[...]

46. Article 7 of the ECN limits this type of loss of nationality in two ways. Firstly, no loss should take place on this ground after the person involved has reached the age of majority. Secondly, statelessness should not be the consequence.

\footnotetext{
${ }^{137}$ De Groot/ Vink 2014, para. 7. See Eudo-citizenship database mode L11.

${ }^{138}$ De Groot/ Wautelet 2014, para. 3.2.

${ }^{139} \mathrm{De}$ Groot/ Wautelet 2014, para. 4.3.

${ }^{140}$ De Groot 2013c, para. 6.
} 
47. In the past few years serious doubts have arisen in several states regarding the age limit mentioned in Article 7, paragraph 1 (f) of the ECN. It is doubtful that the loss of nationality can still be justified when the child involved has been, in a completely legal way, in possession of a nationality for a considerable number of years. This is in particular the case if the child was treated as a national for a period exceeding the period of residence required for naturalisation, which according to Article 6, paragraph 3 of the ECN should not exceed ten years. Furthermore, the desirable preferential treatment of children could even justify a much shorter limit. This principle does not prescribe a certain maximum period after which the non (or no longer) fulfilment of the preconditions for the acquisition should not have consequences. Domestic law has to specify the required period of time. However, it is obvious that this period should be shorter than 18 years (see Article 7, paragraph 4 (f) of the ECN)."

In respect of this ground for loss the ILEC Guidelines 2015 formulate the following recommendations ${ }^{141}$ :

a) If a State provides that the loss of a family relationship is ground for the loss of nationality, in specific circumstances, it should provide so expressly in its nationality law and regulate the conditions and limits of its application;

b) Loss of nationality due to the loss of a family relationship should never cause statelessness;

c) In light of the proportionality principle and the desirability of the protection of legitimate expectations a limitation period is desirable. The required period should be shorter than the residence period required for naturalisation and also shorter than the limitation period which may exist in the state involved for deprivation of citizenship based on fraud;

d) The protection mechanisms (no statelessness; limitation period) should not only apply in cases where the family relationship legally existed, but was annulled, but also in cases where it is discovered that the family relationship never legally existed.

\subsubsection{Choices to be made}

If a State wants to provide this ground for loss it has to regulate the limits of its application.

A rather short limitation period is appropriate, which should be shorter than the limitation period which may exist for deprivation of nationality based on fraud. It is completely unreasonable that the loss of nationality due to loss of a family relationship can occur after a longer possession of nationality in good faith than in case of possession of nationality in bad faith due to committing fraud during the acquisition procedure. It is also difficult to understand why the limitation period should be longer than the residence period required for naturalisation.

${ }^{141}$ ILEC Guidelines 2015, IV.3. Compare also De Groot 2015. 
Moreover, one should realise that the child involved did build up ties with the country of his nationality and will have the expectation to continue to be a national. For these reasons, countries like Finland ${ }^{142}$ and Germany ${ }^{143}$ provide for an age limit of five years in respect of this ground for loss. Finland also explicitly takes into account additional considerations, such as the ties between the target person and the country involved.

This limitation exists in Germany since 2009 and was introduced after the Constitutional Court ruled that a short limitation period had to be introduced. ${ }^{144}$ An exception to the limitation to the age of five years applies in cases where the recognition of paternity is annulled by a court on application of the authorities because this recognition happened for immigration law purposes. ${ }^{145}$ However, this annulment is not possible if a "sozial-familiäre Beziehung" (socio-familial relationship) ${ }^{146}$ exists between the father and the child. Otherwise the annulment of paternity and the consequential loss of nationality would constitute a violation of Art. 8 ECHR.

Of course a State also has to regulate whether the loss happens ex lege if it is established that the family relationship which led to the acquisition of nationality does no longer exist and this happens before completion of the applicable limitation period. However, if a State also wants to take other considerations into account - like e.g. Finland - a deprivation procedure has to be chosen.

\subsubsection{Related grounds for acquisition and loss and related general issues}

The closest related ground for acquisition is of course the acquisition iure filiationis (see above para. 2.1).

Related grounds for loss are not meeting the grounds which were the basis of the acquisition ( e.g. discovery of possession of another nationality, in case of a default acquisition of nationality iure soli by a foundling) ${ }^{147}$ and loss of nationality due to revocation or annulment of adoption. ${ }^{148}$

As for all grounds of loss of nationality procedural issues are essential. Arbitrary effects are forbidden and the proportionality of the loss must be beyond any reasonable doubt. With this ground for loss, the best interests of the child should be paramount and will often have to lead to protection of legitimate expectations. ${ }^{149}$

\footnotetext{
${ }^{142}$ Par. 32 Kansalaisuuslaki (Finish Nationality Act).

${ }^{143}$ Para. 17(3) StAG.

${ }^{144}$ German Constitutional Court Decision: BVerfG, 2 BvR 696/04 of 24.10.2006. See De Groot and Schneider 2007, 79-102.

${ }^{145}$ See Para. 1600 (1) 5 and 1600 (3) in combination with 1592 (2) BGB (German Civil Code).

${ }^{146}$ This expression obviously refers to the concept of 'family life' in the sense of Art. 8(1) ECHR.

${ }^{147}$ Compare Eudo-citizenship database mode A03a.

${ }^{148}$ Eudo-citizenship database mode L13b. See also above para. 2.2.

${ }^{149}$ See hereinafter par 2.7 .
} 


\subsubsection{An assessment of case 5}

According to the nationality law of the Netherlands, Netherlands nationality is lost if the parentage relation which constitutes the ground for the acquisition of Netherlands nationality is annulled during the minority of the child involved, e.g. by a successful denial of paternity. No loss occurs, if the child would otherwise become stateless (Art. 14 (4) RwNed). This rule is in line with Art. 7(1)(f) ECN, but problematic in light of the recommendations of the ILEC guidelines. The Netherlands legislator should revisit the current regulation of this ground for loss in light of the ILEC guidelines and the recent reforms in Finland and Germany. 


\subsection{Procedural safeguards}

\subsubsection{Case 6 Deprivation of nationality due to identity fraud}

Marlene Erdene came as a minor with her mother from Mongolia to the Netherlands in the 1990s and received a residence permit. In 2007 she successfully applied for naturalisation. However, in 2007 the Immigration and Naturalisation Department (IND) received information that Marlene had not entered the Netherlands under her real name. Her real name is Migeddorjiin Bat-Erdene. ${ }^{150}$ Furthermore, her date of birth as mentioned in her residence permit and in the Royal Decree granting naturalisation was not correct (8 Januari 1981 instead of 10 October 1981). In 2010 the Minister of Justice concluded that applying for naturalisation while submitting wrong personal data constituted fraud committed during the naturalisation procedure and that for that reason the naturalisation decree could be annulled under the operation of Art. 14 (1) Rijkswet op het Nederlanderschap. In respect of the proportionality of that decision it was argued that applying for naturalisation using false personal data is such a serious case of fraud that deprivation of nationality by annulment of the naturalisation is appropriate and proportional. Although the decision of the Minister can be challenged in court, the decision has immediate effect, i.e. Netherlands nationality is lost and during the court proceedings the person involved is treated as a foreigner. ${ }^{151}$

\subsubsection{Relevant international standards}

In order to enhance everyone's right to a nationality and in order to implement the ban on arbitrary deprivation as enshrined in Art. 15 UDHR, procedural safeguards are essential. ${ }^{152}$ For decisions on deprivation of nationality this is already recognised by Art. 8 (4) CRS 1961, which provides:

\section{"A Contracting State shall not exercise a power of deprivation permitted} by paragraphs 2 or 3 of this Article except in accordance with law, which shall provide for the person concerned the right to a fair hearing by a court or other independent body."

However, it is evident that procedural safeguards are also of paramount importance for cases of ex lege loss of nationality. Moreover, procedural safeguards are likewise essential in order to guarantee a fair and non-discriminatory access to nationality. This is in particular the case if a person claims to have acquired a

\footnotetext{
${ }^{150}$ This Mongolian name is invented, but is chosen in a way which enabled me to illustrate the differences between the real name of the applicant in the case involved and the name used by her. Although the name of the applicant does not appear in the decision of the Council of State as published online, the real name and the names used by the applicant are known to me.

${ }^{151}$ The case description is based on a decision of the Council of State (Raad van State) as Supreme Administrative Court of the Netherlands of 11 December 2013, ECLI:NL:RVS:2013:2401, Jurisprudentie Vreemdelingenrecht 2014, no. 66, p. 338-342 and the Court of Maastricht 6 March 2013, ECLI:NL:RBLIM:2013:919. See also Chun Luk, in Carrera Nuñez / De Groot 2015, 493, 494. Note that the names used in the case description have been changed.

${ }^{152}$ SG UN 2009. Compare also Brandvoll 2014 and Molnár 2014.
} 
nationality ex lege according the rules of the State concerned or if (s)he is entitled to be registered as national by e.g. the exercise of an option right. If such a person would not have the right to ask a judicial review of her or his nationality position after the authorities refuse to recognise her or him as a national, this would amount to arbitrary deprivation of nationality. ${ }^{153}$ However, if one wants to guarantee that everybody who has built up a genuine link with a country should have a fair and non-discriminatory access to the nationality of that State and arbitrary denial of naturalisation should be impossible, also negative decisions on applications for naturalisation must be open for judicial review.

That procedural safeguards should exist for all decisions on the nationality position of a person is firmly recognised by the ECN 1997. The drafters of the ECN also realised that a judicial review without having a right to receive a written decision would run empty. Moreover, it is of importance to avoid that the exercise of a right to have a judicial review would be hindered by unreasonable fees. ${ }^{154}$ The relevant articles read as follows:

\section{"Article 11 - Decisions}

Each State Party shall ensure that decisions relating to the acquisition, retention, loss, recovery or certification of its nationality contain reasons in writing.

\section{Article 12 - Right to a review}

Each State Party shall ensure that decisions relating to the acquisition, retention, loss, recovery or certification of its nationality be open to an administrative or judicial review in conformity with its internal law.

\section{Article 13 - Fees \\ [...] \\ 2 Each State Party shall ensure that the fees for an administrative or judicial review be not an obstacle for applicants."}

Regrettably, the ECN allows to make reservations in respect to these articles and some Contracting States did. ${ }^{155}$ However, it follows from case law of the ECJ and the ECtHR that at least in cases of loss of nationality ${ }^{156}$ and in cases where it is claimed that the access to nationality is denied on discriminatory grounds ${ }^{157}$, not having access to a judge would violate European law, respectively the European Convention on Human Rights.

\footnotetext{
${ }^{153}$ Compare De Groot/ Swider/ Vonk 2015, para. 5.2.

${ }^{154}$ Furthermore, there should not be a risk that applicants are liable to pay the costs incurred by the State in case of an unsuccessful procedure. See the ILEC Guidelines, III.3.

${ }^{155}$ Denmark made a reservation on Art. 12 for decisions on naturalisation and Hungary made a reservation on Art. 11 and 12 for decisions relating to requests to acquire nationality.

${ }^{156}$ See ECJ 2 March 2010 in Rottmann which prescribes a proportionality test, which implies that a judicial review must be possible. See De Groot/ Seling 2011; Shaw 2011

${ }^{157}$ See ECtHR 11 October 2011 in Genovese v Malta. See De Groot/ Vonk 2012.
} 
In December 2009, the Secretary General of the United Nations, in a report dealing with arbitrary deprivation of nationality, which was sent to the UN Human Rights Council, asked that attention be given to procedural safeguards: ${ }^{158}$

"Procedural safeguards are essential to prevent abuse of the law. States are thus expected to observe minimum procedural standards in order to ensure that decisions on nationality matters do not contain any element of arbitrariness. For example, according to article 17 of the International Law Commission's draft articles on the nationality of natural persons [in case of state succession; $G R d G]$, decisions relating to acquisition, retention or renunciation of nationality should be issued in writing and be open to effective administrative or judicial review. These elements, according to the Commission, "represent minimum requirements in this respect".

The International Law Commission also stated in the above-mentioned commentary on the draft articles that the review process could be carried out by a competent jurisdiction of an administrative or judicial nature in conformity with the internal law of each State. The Commission clarified that the term "effective" was intended to stress the fact that an opportunity had to be provided to permit meaningful review of relevant substantive issues; [...]

it could thus be understood in the same sense as in article 2, paragraph 3 (a), of the International Covenant on Civil and Political Rights, where the same word is used.

Moreover, the Commission stressed that the word "judicial" should be understood as covering both civil and administrative jurisdictions."

In his report to the Human Rights Council of December 2013, the Secretary General underscored furthermore: ${ }^{159}$

"Where a person is subject to loss or deprivation of nationality and a review process is available, lodging an appeal should suspend the effects of the decision, such that the individual continues to enjoy nationality - and related rights - until such time as the appeal has been settled. Access to the appeals process may become problematic and related due process guarantees nullified if the loss or deprivation of nationality is not suspended and the former national, now alien, is expelled. Similarly, if withdrawal of nationality results in the loss of property rights, the individual may have to forfeit his home or business, as well as other acquired rights - an interference which may be difficult to repair if it is subsequently established that the loss or deprivation of nationality was unlawful or arbitrary and must be reversed." 160

\footnotetext{
${ }^{158}$ SG UN 2009, para. 43, 44.

${ }^{159}$ SG UN 2013, para. 31 and 33.

${ }^{160}$ See also the 2013 Tunis Conclusions, para. 26 and 27.
} 
In line with the just described documents the ILEC Guidelines 2015 provide the following procedural guidelines: ${ }^{161}$

"Banning arbitrary deprivation and the necessity of applying a proportionality test imply that adequate procedural safeguards are essential. These safeguards apply in all cases of loss and deprivation, including in cases where authorities conclude that a given person never acquired a nationality.

1. All decisions relating to the loss and deprivation of nationality need to be provided in writing, and have to contain explicit reasons for the deprivation.

2. All decisions relating to the loss or deprivation of nationality should be open to judicial review, i.e. access to an independent judge leading to a reasoned decision;

3. The fees for judicial review should not be an obstacle for applicants. Applicants should not be held liable to pay the costs incurred by the State, even if they fail to successfully challenge the deprivation.

4. During the procedure, applicants should be treated as nationals; this treatment should be afforded during appeals procedure, including any recourse to supranational courts. However, a state may use the construction of retroactivity after a final decision cannot challenged anymore.

5. Decisions should only take effect when the (judicial) decision cannot be challenged anymore."

\subsubsection{Choices to be made}

The abovementioned international standards do not leave much room for own fundamental choices. However, the choice of the type of courts which will deal with nationality issues (civil, criminal or administrative courts) is within the margin of appreciation of the States. Of course, the choice should fit the general structure of the judiciary of the State. The same applies for procedural law issues. However, in respect of the burden of proof and the standard of proof, the guidelines of the UNHCR have to be taken into account by a court in cases where the answer to the question of whether or not a person possesses a foreign nationality is relevant for the acquisition or loss of nationality. ${ }^{162}$ In particular, a court should never conclude that a person is in possession of the nationality of a particular other State, if the authorities of this other State persist to deny this. ${ }^{163}$

\footnotetext{
${ }^{161}$ ILEC Guidelines 2015, III.

${ }^{162}$ UNHCR Guidelines on statelessness No 4, para. 19-21; Tunis Conclusions 2013, para. 7 and 8; De Groot 2013c, para. 7.

${ }^{163}$ Regrettably, the British Supreme Court seems to do so in the decision of 25 March 2015 dealing with the possible deprivation of British nationality of a Mr. Pham of Vietnamese origin. The deprivation could only take place if he was in possession of Vietnamese nationality, which was persistently denied by the Vietnamese authorities. Nevertheless, the Supreme Court concluded that he was a Vietnamese national. See UKSC 2013/0150, in particular para. 38.
} 
Doing otherwise was labelled by François Laurent as juridical heresy (hérésie juridique) already as far back as $1887 .{ }^{164}$

And of course a State has to regulate the fees due for procedures. These must be reasonable in light of the average wages in the country. Attention has also has to be paid to the financial consequences of an unsuccessful procedure. There should be no risk that the applicant in that case has to pay the costs made by the State.

\subsubsection{Relevant grounds for acquisition and loss and related general issues}

As already mentioned above in para. 2.6.1, procedural safeguards are essential for all grounds of acquisition and loss. They need particular attention in quasi-loss situations, where authorities come to the conclusion that a person never acquired the nationality, although the person concerned was treated as a national in the past and will therefore experience this "non-acquisition" as loss of nationality. ${ }^{165}$

Procedural safeguards are intimately linked with other general issues, inter alia with the ban on arbitrary deprivation of nationality, equal treatment, non-discrimination and the protection of legitimate expectations (see below para. 2.7).

\subsubsection{An assessment of case 6}

International standards allow the deprivation of the nationality acquired by naturalisation or a similar procedure if fraud was committed during the procedure and the deprivation of nationality is a proportional reaction in light of the severity of the fraud, the time that has passed since the fraud, the consequences of the deprivation of nationality for the person involved and the members of the family etcetera. In the case described above no attention is paid to the different relevant issues and circumstances. In particular, no attention is paid to the question whether or not a criminal record was discovered after the authorities received information about the real name and date of birth of the person involved. Furthermore, no relevance was awarded to the fact that she started to use the wrong name and date of birth as a minor. Although the Minister said to apply a proportionality test, this certainly did not happen in a way as prescribed by the Rottmann ruling of the Court of Justice of the European Union. ${ }^{166}$

Critical remarks are also appropriate as regards the degree of "fraud". The difference regarding the date of birth was only 10 months. In the case Hirsi Ali ${ }^{167}$ a difference of two years was at the end not sufficient to conclude that there was a relevant identity fraud. Furthermore, in the case described above the applicant used an obvious Western first name "Marlene", whereas in Mongolia her birth

\footnotetext{
${ }^{164}$ Laurent 1887, no. 385, p. 493.

${ }^{165} \mathrm{De}$ Groot/ Wautelet 2014. See ILEC Guidelines 2015, V.

${ }^{166}$ See for more details my very critical case note in Jurisprudentie Vreemdelingenrecht 2014 , no. 66, p. $338-342$

${ }^{167}$ See on that case De Groot $2007 b$.
} 
certificate indicated the name "Migeddorjiin". However, it is quite common in the Far East to use in social contact with Westerners a "Western" first name, which is often also used on business cards. In respect of the family name we can also observe a particularity. Entering the Netherlands she used the family name "Erdene", while the full family name is "Bat-Erdene". The difference is only one syllable. Does this already constitute identity fraud? I have severe doubt about this. ${ }^{168}$

Another major problem is the immediate effect of the deprivation of nationality. A reasonable interpretation of international standards as following from inter alia the Rottmann ruling implies that the deprivation should only become effective once all judicial remedies have been exhausted. The legislator of the Netherlands should regulate that expressly. If a court is confronted with this issue, it could order that the State has to treat the person involved as a national during the proceedings. If a judge hesitates to do so, it is appropriate to initiate a preliminary ruling procedure in order to ask guidance from the Court of Justice of the European Union.

${ }^{168}$ Would I commit identity fraud, if I would present myself as "Groot" instead of "De Groot"? 


\subsection{Protection of legitimate expectations}

\subsubsection{Case 7 Extension of naturalisation?}

Twin girls Natasja and Olivia were born in 1995 in Paramaribo (Suriname). The parents were Surinamese spouses living in Aruba. After they discovered that the wife was pregnant with twins, the spouses decided that the delivery of the babies should take place in the hospital of Paramaribo due to its good reputation. Some days after the birth of the girls the whole family returned to Aruba. In 1998 the parents acquired Netherlands nationality by naturalisation. According to the text of Art. 11 of the Kingdom Statute on Netherlands nationality (as in force between 1985 and 2003) the naturalisation of a parent included the naturalisation of minor children, except if a child was expressly excluded from this extension of naturalisation. However, between 1992 and 2003 all Royal Decrees of naturalisation included the proviso that minor children whose residence in the Kingdom of the Netherlands was not covered by a residence permit allowing residence for indefinite time were excluded from this extension of naturalisation. ${ }^{169}$ Following the naturalisation of their parents, the twins were registered as Netherlands nationals in the population register. They received Netherlands passports, which were several times renewed. Having finished their secondary school education in 2014, the girls wanted to study in the Netherlands. They applied for new passports, but their applications were rejected by the Cabinet of the Kings Governor of Aruba due the fact that the Aruban Immigration Department (Departamento di Integracion, Maneho y Admision di Stranhero (DIMAS)) did not find copies in their files of their residence permits valid on the day of the naturalisation of their parents 16 years earlier. Consequently, it was concluded that Natasja and Olivia never acquired Netherlands nationality by extension of the naturalisation of their parents. ${ }^{170}$

\subsubsection{Relevant international standards}

Above in para. 2.6.4 it was already mentioned that a close relationship exists between the ban on arbitrary deprivation of nationality and the protection of legitimate expectations. This is in particular true for the treatment of a person as a national. If after such treatment authorities come to the conclusion that the person concerned is not a national, this will be experienced as loss. ${ }^{171}$ If the legitimate expectation to be treated as a national also in the future is not protected, this may amount to arbitrary deprivation of nationality.

In his opinion in the Rottmann case, Advocate General Poiares Maduro also mentioned the principle of the protection of legitimate expectations as one of the general principles of European law which may have consequences for the nationality law of Member States:

\footnotetext{
${ }^{169}$ The relevant formulation was: "Het Nederlanderschap is onthouden aan de minderjarige kinderen aan wie geen verblijf voor onbepaalde tijd in Nederland, onderscheidenlijk de Nederlandse Antillen en Aruba, is toegestaan."

${ }^{170}$ This case was brought to my attention by a lawyer on behalf of the Minister of Justice of Aruba who was very embarrassed about the rejection by the Cabinet of the Governor of the twins' application for new passports.

${ }^{171}$ De Groot/ Wautelet 2014.
} 
"As regards the withdrawal of naturalisation at issue in this case, some might invoke against it the principle of the protection of legitimate expectations as to maintenance of the status of citizen of the Union." ${ }^{172}$

However, in the Rottmann case there was no need to protect the expectations of Rottmann, because these were absolutely not legitimate due to the fraud committed by him.

The need of protection of legitimate expectations is also the background of Principle 18 of Recommendation 2009/13 of the Committee of Ministers of the Council of Europe on the position of children in nationality law. As already mentioned above in para. 2.5.1 Member States are recommended to:

"provide that children who were treated in good faith as their nationals for a specific period of time should not be declared as not having acquired their nationality;"

Para. 45 of the Explanatory Memorandum deals with the need of protecting legitimate expectations:

"45. It has to be stressed that Article 7, paragraph 1 (f) of the ECN also applies if it is established that, for instance, the family relationship which constituted the basis of the acquisition of the nationality of the child, was registered by mistake. The latter may be the case if for example the identity of the parent, which is relevant for the jure sanguinis acquisition of nationality, is discovered to be wrong, or in situations where it is discovered, after acquisition of the nationality by an ex lege extension of naturalisation, that no family relationship ever existed between the parent and the child."

Consequently the discovery of these facts should never cause statelessness. Furthermore, the child concerned should also after the discovery of these facts be in possession of the nationality if (s)he was treated as a national for a specific period of time determined by domestic law.

The ILEC Guidelines 2015 deal with the protection of legitimate expectations in the context of so-called quasi-loss of nationality: ${ }^{173}$

"In all cases of quasi-loss, and whatever characterization is retained by a state (i.e. constructing a situation of quasi-loss as a case of loss, deprivation or annulment of acquisition), States should strive to protect the legitimate expectations of the persons concerned. The extent and strength of this protection may vary depending on the specific circumstances of the case. When a person has

\footnotetext{
${ }^{172}$ AG Poiares Maduro, Opinion in re Rottmann, para. 31.

${ }^{173}$ ILEC Guidelines 2015, V.b. See also De Groot/ Wautelet 2014.
} 
enjoyed the benefit of a nationality for a period exceeding the maximum number of years required to acquire it by naturalisation, the State concerned should consider that such nationality was indeed duly acquired.

When a case of quasi-loss is discovered, States should preferably attempt to guarantee the continuation of the nationality of the person concerned. States are free to decide what mechanism or device they wish to use to guarantee such continuation. It may be that under the relevant national law, such continuation is achieved through the legal instrument of apparent status of national (possession d'état de nationalité), through an administrative recognition of nationality, or through another device. It is advisable to combine such legal instruments with limitation provisions."

The ILEC Guidelines also pay attention to the procedural dimension of the protection of the legitimate expectations:

"In order to determine the extent to which legitimate expectations deserve protection, a state should take into account all relevant circumstances of each individual case and apply a proportionality test.

If a state intends to extend the consequences of a situation of quasi-loss to members of the family of the person concerned, i.e. spouses or children, separate decisions on their nationality are necessary, which cannot be automatic replicas of the decision taken for the person concerned. These decisions should instead be taken after an individual assessment of the position of the spouse and/or children taking into account a proportionality test.

If the decision to consider that a person can be deprived of his nationality was based on the fraudulent conduct of this person, this conduct cannot automatically be attributed to the spouse and/or children of the person. Such attribution can never take place in relation to children, if the adult only pretended to be the legal representative."

In all cases concerning children involved in a quasi-loss situation, the decision should in the first place be guided by the best interests of the child.

\subsubsection{Choices to be made}

Of course a State has to decide after a how long period of treatment as a national in good faith legitimate expectations will be protected. As both the Explanatory Memorandum on Recommendation 2009/13 and the ILEC Guidelines point out (see above para. 2.7.1) the required length of that period may vary for different categories (e.g. shorter for children in light of the best interests of the child). 
A way to honour the legitimate expectations is to provide for a naturalisation, preferably free of charge. ${ }^{174}$ However, although this approach may work sometimes, it has considerable disadvantages. First, the naturalisation will - in principle $^{175}$ - lack retroactivity. If the person concerned has descendants who were supposed to have acquired their nationality iure filiationis because of the nationality of the person concerned, her or his naturalisation - without retroactivity - does not rescue the nationality of these descendants. They also have to be naturalised. Second, and this is the most important disadvantage, is a State willing to apply the process of naturalisation also in cases where the person involved deserves to have legitimate expectations protected but has a criminal record?

For those reasons a guarantee of the continuation of the possession of nationality is preferable. As the ILEC Guidelines cited above in 2.7.1 indicate, States are free to decide what mechanism or device they wish to use to guarantee such continuation. Such decisions should fit the general structure of the legal system. In France and in legal systems influenced by the French tradition, this is certainly the consolidation of the nationality status due to having possessed during a specified period the apparent status of a national (possession d'état de nationalité). ${ }^{176}$ In common law systems in the field of nationality one could follow the example of the United Kingdom by using the construction of an administrative recognition of nationality. ${ }^{177}$ But another option is the construction followed by Germany: ${ }^{178}$

"German citizenship shall also be acquired by any person who has been treated by German public authorities as a German national for 12 years and this has been due to circumstances beyond his or her control. In particular, any person who has been issued a certificate of nationality, a passport or a national identity card shall be treated as a German national. Acquisition of citizenship shall apply as of the date when the person was deemed to have acquired German citizenship by treating him or her as a German national. The acquisition of German citizenship shall extend to those descendants who derive their status as Germans from the beneficiary pursuant to sentence 1."'179

\footnotetext{
${ }^{174}$ Compare the solution followed in the Netherlands for cases where the treatment as national is based on mistakes made by the competent authorities. See Handleiding voor de toepassing van de Rijkswet op het Nederlanderschap, comment in para. 2.3 on Art. 10 RwNed.

${ }^{175}$ However, giving naturalisation retroactivity is unusual but would in my opinion not violate international standards.

${ }^{176}$ Art. 21-13 Cc français and Art. 18 Cc esp..

${ }^{177}$ De Groot/ Wautelet 2014, para. 6.3.

${ }^{178}$ Par. 3 StAG.

179 English translation available on http://eudo-citizenship.eu/admin/?p=file\&appl=currentCitizenshipLaws\&f=G ER\%20Nationality\%20Act\%20\%28English\%20consolidated\%20version\%201\%20June\%202012\%29.pdf.

The German original text reads: "Die Staatsangehörigkeit erwirbt auch, wer seit zwölf Jahren von deutschen Stellen als deutscher Staatsangehöriger behandelt worden ist und dies nicht zu vertreten hat. Als deutscher Staatsangehöriger wird insbesondere behandelt, wem ein Staatsangehörigkeitsausweis, Reisepass oder Personalausweis ausgestellt wurde. Der Erwerb der Staatsangehörigkeit wirkt auf den Zeitpunkt zurück, zu dem bei Behandlung als Staatsangehöriger der Erwerb der Staatsangehörigkeit angenommen wurde. Er erstreckt sich auf Abkömmlinge, die seither ihre Staatsangehörigkeit von dem nach Satz 1 Begünstigten ableiten."
} 


\subsubsection{Relevant grounds for acquisition and loss and related general issues}

Protection of legitimate expectations may be relevant for all grounds for automatic acquisition or loss, but also for cases of naturalisation or acquisition of nationality by registration or option, if the acquisition later proves to be defective.

The link between protection of legitimate expectations and the risk of arbitrary deprivation was already indicated above in para. 2.7.1. There is also an evident link with the equality principle.

\subsubsection{Assessment of case 7}

The non-existence of the protection of legitimate expectations in the nationality law of the Netherlands is extremely problematic in view of general principles of European Union law. As mentioned above, the protection of legitimate expectations was mentioned as a general principle of EU law with relevancy for the nationality law of Member States. Not protecting such legitimate expectations amounts to quasi-loss of nationality and can be qualified as arbitrary loss. The legislator of the Kingdom of the Netherlands should undertake action to enshrine a rule on protection of legitimate expectations in the nationality legislation. How should a judge react when confronted with a case such as that of the twins? First, a judge could decide to apply the principle of protection of legitimate expectation as a principle of European law. However, due to the fact that the highest courts in the Netherlands repeatedly stressed that Netherlands nationality law does not include this principle, it would be wise to initiate a preliminary ruling procedure and ask the Court of Justice of the European Union for guidance. ${ }^{180}$

\footnotetext{
${ }^{180}$ The case involved was "solved" in a surprising way. Nothing prevents a residence permit being granted with retroactivity. The government of Aruba decided to use that possibility and granted a residence permits with 18 years' retroactivity (bekrachtiging verblijfstitel medegenaturaliseerden). This "saved" the extension of the parents' naturalisation. See the decision of the Gemeenschappelijk Hof van Justitie van Aruba, Curaçao, Sint Maarten en van Bonaire, Sint Eustatius en Saba of 19 May 2015, HAR 63/14, Due to the fact that there are quite a number of similar cases in Aruba, the government enacted a Decree where the same solution was adopted in other cases. This approach was also followed by the government of Curaçao.
} 


\section{Concluding observations}

Please realise that in this lecture I could only offer a first impression of the toolbox that I propose. The description of the standards, but in particular the choices to be made, the analysis of the advantages and disadvantages of the different options and the inventory of best practices have to be elaborated considerably and should be based on the rules and practices in all States of the world. Developing such a toolbox is a project on which an international and interdisciplinary team of experts should work. The toolbox project will prove to be useful for States dealing with nationality law issues, and in particular would facilitate discussions on the national level between stakeholders in debates on nationality law reforms.

But the project makes it also possible to identify issues which should be subject of (further) discussion and action on the international level in view of developing new, more detailed rules.

It is clear that all modes of acquisition and loss of nationality as listed in the Eudo-citizenship database deserve attention, either separately or in combination with each other. Relationships between the different modes have to be identified and analysed. In order to enable the drafters of the toolbox to refer to rules and practices stemming from all over the world, it is necessary to include all States in the Eudo-citizenship global database and to constantly update the global database. ${ }^{181}$

A careful selection has to be made of general issues that deserves separate attention. Besides the examples given in this lecture, candidates for being selected are: arbitrary deprivation of nationality ${ }^{182}$, the proportionality principle ${ }^{183}$, the avoidance of statelessness ${ }^{184}$, multiple nationality ${ }^{185}$, quasi-loss of nationality ${ }^{186}$, equality of men and women in nationality law. ${ }^{187}$

You will understand that I am willing to continue working on the toolbox that I am proposing, but I also stress that it is essential to share the workload with an international team of experts. Working on the toolbox will hopefully also enhance discussions - both academically and politically - on the improvement of nationality laws worldwide.

\footnotetext{
${ }^{181}$ It is great that in 2015 the Americas could be added to the database (Vonk e.a.). Work in the MENA area (Van Waas e.a.), Africa (Manby e.a.) and the Far East and Oceania (Vonk e.a.) is in progress.

${ }^{182}$ Compare the ILEC Guidelines, sub I: General guidelines on loss of nationality; De Groot 2013c, para. 6.

${ }^{183}$ Compare the ILEC Guidelines, sub II: The principle of proportionality; De Groot/Vink 2014, para.3.2.

${ }^{184}$ Blitz/ Lynch 2011; Edwards/ Van Waas 2014; De Groot/Swider/ Vonk 2015; Manly/ Van Waas 2014; Sawyer/ Blitz 2011; Stiller 2011; Vonk/ De Groot 2013/ 2014; Van Waas 2008/ 2011/ 2012/ 2014

${ }^{185}$ De Groot/ Vink 2008; Pitkänen/ Kalekin-Fishman 2007; Vonk 2012.

${ }^{186}$ De Groot/ Wautelet 2014.

${ }^{187}$ De Groot 2012b; see also the report of the UNHCR on Background Note on Gender Equality, Nationality Laws and Statelessness 2015, 6 March 2015, available at: http://www.refworld.org/docid/54f8369b4.html .
} 


\section{Some words of thanks}

At the end of this valedictory lecture it is appropriate to say words of thanks. I will not repeat the words of gratitude expressed in my inaugural lecture for the academic education I enjoyed in Groningen, Münster and Maastricht. ${ }^{188} \mathrm{I}$ am sure that the inspiration of the examples of my academic professors and supervisors is still visible in my work. However, I want to make two exceptions.

I thank wholeheartedly my dear Professor Hans-Ulrich Jessurun d'Oliveira. He was my professor for comparative law and legal philosophy at Groningen University, 45 years ago. But a bit later, both of us developed a strong interest in nationality and migration issues. During the past 40 years we frequently had debates with each other on these issues: sometimes in public, ${ }^{189}$ more often privately. Dear Ulli, you are a constant source of inspiration. I am grateful that you accompanied me during my whole academic career. Please continue to do that in the future.

Furthermore, I want to thank Professor Bernard Grossfeld for his hospitality at the Institute of Comparative Law of the University of Münster (Germany). To work in that institute and have many talks with Grossfeld was extremely inspiring for me. He furthermore introduced me to the German-Netherlands Lawyers Association $^{190}$, of which I later became the Netherlands Chairman. ${ }^{191}$

Having worked at Maastricht University for 35 years I owe a lot to many of my Maastricht colleagues in past and present. It would not be difficult to sum up at least hundred names of persons important for me. I will not do so, but again make some exceptions.

It was a privilege to have been one of the members of staff building up a law department here in Maastricht. With great satisfaction I can now witness the many successes of this department. Of the colleagues with whom I collaborated in the first years of my work here in the 1980's in Maastricht, I want to mention in particular Theo van Boven, Job Cohen, Karl Dittrich, Kees Flinterman, Marijke van Hoof, Victor Rutgers en Marlie Sprengers. I am in particular grateful that Kees acted 28 years ago as the supervisor of my thesis.

Susan Rutten I want to thank for working with me for a period of some 30 years. We share a profound interest in developments in international family law, with a focus on challenges caused by the presence of an increasing number of people in our society with roots in the Islamic world. You are now professor of Islamic

\footnotetext{
${ }^{188}$ De Groot 1989.

${ }^{189}$ Jessurun d'Oliveira 1978, 1989, 1990, 2011, 2013 and 2016.

${ }^{190}$ Deutsch-Niederländische Juristenkonferenz. See http://www.deutsch-niederlaendische-juristenkonferenz.de/

${ }^{191}$ I want to thank Carel Molenaar, Chantal Kuijpers and Yleen Simonis for their assistance with organising these conference biannually in the Netherlands.
} 
family law in a European context and the chair of the Dutch Association for the Study of Islamic Law (RIMO ${ }^{192}$ ), which I co-founded in the early 1980s. I am happy that RIMO is flourishing in your hands with firm assistance of inter alia Pauline Kruiniger. You both were also - together with Stephan Rammeloo, Kees Saarloos and Michael Wells-Greco ${ }^{193}$ - indispensable for teaching Private International Law and Family Law in Europe.

Speaking about teaching, I have to mention Catalina Goanta without whom my course Introduction to Comparative Law would never have received such high student evaluations as it did in the past five years.

My chair was part of the department of Private Law. Next to Susan Rutten, I want to thank the other chair holders in the department for their smooth cooperation and friendship. I want to mention in particular Jan Smits, Sjef van Erp, Ton Hartlief, Mieke Olaerts, Kid Schwarz and last but not least professor emeritus Gerrit van Maanen, together with whom I started my academic career at Groningen University more than 42 years ago. I am also grateful for the excellent assistance of our secretariat and want to mention in particular Margriet van Woerden and José Crijnen.

For my research activities in the past ten years Maarten Vink, Professor of Political Science and Political Sociology in de Faculty of Arts and Social Sciences was indispensable. I thank you for your willingness to embark together with me on so many interdisciplinary projects regarding nationality and citizenship. I think that our collaboration shows perfectly how fruitful an interdisciplinary approach can be. This is also illustrated by our collaborations as co-directors of MACIMIDE $^{194}$, where I also enjoyed the inspiring ideas of Valentina Mazzucato and Melissa Siegel. I am also grateful for the cooperation with colleagues within CERiM $^{195}$, in particular with Ellen Vos and Bruno De Witte. For their intensive collaboration in joint projects I also have to thank, among many others and in alphabetical order, Rainer Bauböck, Sergio Carrera Nuñez, Jo Shaw, Olivier Vonk, ${ }^{196}$ Laura van Waas and Patrick Wautelet. It was great working with you and I hope to be able to continue to do so for many years.

I want to stress that in particular I very much enjoyed to supervise $\mathrm{PhD}$ candidates. I had the privilege of conferring the degree of doctor on - until now - 27 persons. I always learned a great deal from their research, their questions and their answers. I am happy that several $\mathrm{PhD}$ candidates are still in the pipeline. I am looking forward to continue to work with them and accompany them until the moment they will earn their doctorate.

\footnotetext{
${ }_{192}$ Vereniging voor de bestudering van het Recht van de Islam en het Midden-Oosten. See http://www.verenigingrimo.nl/.

${ }^{193}$ I also want to thank Michael Wells-Greco for correcting the English of this lecture.

${ }^{194}$ Maastricht Centre for Citizenship, Migration and Development. See https://macimide.maastrichtuniversity.nl.

${ }^{195}$ Centre for European Research in Maastricht. See https://cerim.maastrichtuniversity.nl.

${ }^{196} \mathrm{I}$ am particularly grateful that Olivier Vonk was willing to send me his comments on the draft text of this lecture.
} 
Finally, I want to express my very special gratitude to three persons.

First, I thank the Dean of the Faculty of Law, Professor Hildegard Schneider for all her support in the University, but more importantly privately. Without you, Dear Hildegard my life would be completely different.

I want to dedicate this lecture in gratitude to my children David and Sophia. The lecture had its focus on the future, not on the past, but was firmly based on past experiences. The University is a community of older and younger people working together in order to achieve - based on knowledge gathered in the past and new research - a better future for all, in particular for coming generations. And, of course, both of you are for me the most important representatives of the younger generation.

Ruit hora: 47 years ago - in August 1969- I started to study law at Groningen University. In the first week of the academic year all students received the Tabula Academica Universitatis Groninganae, a poster with the names of all university professors with indication of their chair. The given names were Latinised and the description of their chair was in Latin. For each department the list of professors started by the professores emeriti. After their names, the following words were added: propter aetatum immunis, quantum poterit, commilitonum studia adiuvabit. ${ }^{197} \mathrm{He}$ helps when is able to do so.

After the rite de passage of which this lecture was the main part, I will also be professor emeritus and I therefore pledge solemnly: adiuvaro quantum potuero.

\section{Dixi}

${ }^{197}$ I am grateful that Rolf ter Sluis, conservator Universiteitsmuseum RUG, sent me a photograph of the Tabula Academiae of the year 1969 . 


\section{List of abbreviations of international treaties, protocols and recommendations}

ACC 1990 African Charter on the Rights and Welfare of the Child AmCHR 1969 American Convention on Human Rights

ArCHR 2004 Arab Charter on Human Rights

ASEAN 2012 ASEAN Declaration of Human Rights

CEDAW 1979 Convention on the Elimination of All Forms of Discrimination against Women

CERD 1966 International Convention on the Elimination of All Forms of Racial Discrimination

CISC 1995 Commonwealth of Independent States Convention on Human Rights and Fundamental Freedoms

CNMW 1957 Convention on the Nationality of Married Women

CRCI 2005 Covenant on the Rights of the Child in Islam

$\mathrm{CRC}$

1989 Convention on the Rights of the Child

CRD 2006 Convention on the Rights of Persons with Disabilities

CRS 1961 Convention on the Reduction of Statelessness

DASS 1999 Draft Articles by the International Law Commission on Nationality of Natural Persons in Relation to the Succession of States

ECAC 1967 European Convention on the Adoption of Children (revised in 2008)

ECN 1997 European Convention on Nationality

ECSS 2006 Council of Europe Convention on the Avoidance of Statelessness in Relation to State Succession

HAC Hague Adoption Convention (= 1993 Hague Convention on protection of children and co-operation in respect of intercountry adoption)

HCNL 1930 Hague Convention on Certain Questions relating to the Conflict of Nationality Laws

ICCPR 1966 International Covenant on Civil and Political Rights

ILEC Involuntary Loss of European Citizenship

OPAN 1963 Optional Protocol Concerning Acquisition of Nationality (belonging to the Convention on Consular Relations)

Rec 2009/13 Recommendation CM/Rec (2009)13 of the Committee of Ministers to member states of the Council of Europe on the nationality of children

UDHR 1948 Universal Declaration of Human Rights 


\section{Other Abbreviations}

ACIT Access to Citizenship and its Impact on Immigrant Integration BC Before Christ

BNA British Nationality Act

Cc esp. Código civil español (Civil code of Spain)

$\mathrm{Cc}$ fran. $\quad$ Code civil français (Civil code of France)

CETS Council of Europe Treaty Series

$\mathrm{CoE} \quad$ Council of Europe

c.s. cum suis (and associates)

e.g. exempli gratia (for example)

EUDO European Union Democracy Observatory on Citizenship

CJEU Court of Justice of the European Union

ECHR European Convention on Human Rights

ECJ European Court of Justice

ECtHR European Court of Human Rights

ETS European Treaty Series

HRC Human Rights Council

i.a. inter alia (amongst others)

ICJ International Court of Justice

i.e. $\quad$ id est (this is)

ILC International Law Commission

LNTS League of Nations Treaty Series

OAS Organization of American States

OAU Organisation of African Unity

pp. pages

para. paragraph

RwNed Rijkswet op het Nederlanderschap (Nationality Act of the Netherlands)

SG UN Secretary General of the United Nations

StAG Staatsangehörigkeitsgesetz (Nationality Act of Germany)

StBG Staatsbürgerschaftsgesetz (Nationality Act of Austria)

TEU Treaty on European Union

TFEU Treaty on the Functioning of the European Union

UN United Nations

UNHCR United Nations High Commissioner for Refugees

UNTS United Nations Treaty Series 
Glossary of Latin terms

\begin{tabular}{|c|c|}
\hline De facto & factually; in fact \\
\hline De iure & legally \\
\hline Ex lege & by operation of the law, automatically \\
\hline Ex nunc & without retroactivity \\
\hline Ex officio & by virtue of office or position \\
\hline Ex tunc & with retroactivity \\
\hline Guardian ad litem & $\begin{array}{l}\text { representative appointed by a court in order to } \\
\text { represent a minor in certain legal proceedings }\end{array}$ \\
\hline Iure filiationis & by ius filiationis \\
\hline Iure sanguinis & by ius sanguinis \\
\hline Iure soli & by ius soli \\
\hline Ius filiationis & $\begin{array}{l}\text { Lit.: right of the parentage: a person acquires } \\
\text { the nationality of a parent at birth or by } \\
\text { the establishment of a child-parent family } \\
\text { relationship. See also ius sanguinis }\end{array}$ \\
\hline Ius sanguinis & $\begin{array}{l}\text { Lit.: right of the blood: a person acquires } \\
\text { the nationality of a parent at birth or by } \\
\text { the establishment of a child-parent family } \\
\text { relationship. N.B.: the expression ius filiationis } \\
\text { is more accurate! }\end{array}$ \\
\hline Ius filiationis a matre & $\begin{array}{l}\text { Lit.: right of the parentage from the mother: a } \\
\text { person acquires the nationality of the mother at } \\
\text { birth or by the establishment of a child-mother } \\
\text { family relationship. See also ius sanguinis a } \\
\text { matre }\end{array}$ \\
\hline Ius filiationis a patre & $\begin{array}{l}\text { Lit.: right of the parentage from the father: a } \\
\text { person acquires the nationality of the father at } \\
\text { birth or by the establishment of a child-father } \\
\text { family relationship. See also ius sanguinis a patre }\end{array}$ \\
\hline
\end{tabular}




\begin{tabular}{|l|l|}
\hline Ius sanguinis a matre & $\begin{array}{l}\text { Lit.: right of the blood from the mother: a person } \\
\text { acquires the nationality of the mother at birth or } \\
\text { by the establishment of a child-mother family } \\
\text { relationship. N.B.: the expression ius filiationis a } \\
\text { matre is more accurate! }\end{array}$ \\
\hline Ius sanguinis a patre & $\begin{array}{l}\text { Lit.: right of the blood from the father: a person } \\
\text { acquires the nationality of the father at birth or } \\
\text { by the establishment of a child-father family } \\
\text { relationship. N.B.: the expression ius filiationis a } \\
\text { patre is more accurate! }\end{array}$ \\
\hline Ius soli & $\begin{array}{l}\text { Lit.: right of the soil: a person acquires the } \\
\text { nationality of his country of birth }\end{array}$ \\
\hline $\begin{array}{l}\text { Nulla perditio sine } \\
\text { praevia lege }\end{array}$ & $\begin{array}{l}\text { Lit.: no loss [of nationality] without a previous } \\
\text { law [which provides for the loss] }\end{array}$ \\
\hline $\begin{array}{l}\text { Pater est quem } \\
\text { matrimonium } \\
\text { demonstrat }\end{array}$ & $\begin{array}{l}\text { The husband of the mother is the legal father of } \\
\text { the child }\end{array}$ \\
\hline
\end{tabular}




\section{Bibliography}

- T. Alexander Aleinikoff and Douglas B. Klusmeyer (ed.), Citizenship Today: Global Perspectives and Practices, Washington, DC: Carnegie Endowment for International Peace 2000.

- Blitz, Brad K. and Maureen Lynch (eds) (2011), Statelessness and Citizenship: A comparative Study on the Benefits of Nationality, Cheltenham: Edward Elgar, pp. 1-22.

- Brandvoll, Jorunn (2014), "Deprivation of nationality: Limitations on rendering persons stateless under international law", in Alice Edwards and Laura van Waas (eds), Nationality and statelessness under international law, Cambridge: Cambridge University Press, pp. 194-216.

- Bauböck, Rainer (2015), Ius filiationis: a defence of citizenship by descent, in: Dumbrava, Costica and Rainer Bauböck (2015), Bloodlines and belonging: Time to abandon ius sanguinis?, EUI Working Papers, RSCAS 2015/80, Robert Schuman Centre for Advanced Studies, EUDO Citizenship Observatory, pp. 6-10, available on http://cadmus.eui.eu/bitstream/handle/ 1814/37578/RSCAS_2015_80.pdf? sequence=1\&isAllowed=y.

- Carrera, Sergio and Gerard-René Groot (2014), "European Citizenship at a Crossroads. Enhancing European Cooperation on Acquisition and Loss of Nationality" (2014), available on www.ceps.eu/system/files/No\%2072\%20 European\%20Citizenship\%20at\%20Crossroads.pdf.

- Carrera Nuñez, Sergio and Gerard-René de Groot (2015), European citizenship at the Crossroads: The Role of the European Union on Loss and Acquisition of Nationality, Oisterwijk: Wolf Legal Publishers 2015.

- de Groot, David (2015), "Law by blood or blood by law?", in: Dumbrava, Costica and Rainer Bauböck (2015), Bloodlines and belonging: Time to abandon ius sanguinis?, EUI Working Papers, RSCAS 2015/80, Robert Schuman Centre for Advanced Studies, EUDO Citizenship Observatory, pp. 30-32, available on http://cadmus.eui.eu/bitstream/handle/1814/37578/ RSCAS_2015_80.pdf? sequence $=1 \&$ isAllowed $=y$.

- de Groot, Gerard-René (1975), Nationaliteitsrecht en emancipatie van de vrouw in de Bondsrepubliek, in: Nederlands Juristenblad (NJB) 1975, pp. 782-787.

- de Groot, Gerard-René (1977), Gelijkheid van man en vrouw in het nationaliteitsrecht, preadvies voor de Nederlandse Vereniging voor Rechtsvergelijking, nr.25, Deventer: Kluwer 1977. 
- de Groot, Gerard-René e.a. (1978)), Debat over het pre-advies van Mr. G.R. de Groot, Gelijkheid van man en vrouw in het nationaliteitsrecht, Nederlandse Vereniging voor Rechtsvergelijking nr. 26, Deventer: Kluwer 1978, pp. 44-51.

- de Groot, Gerard-René (1988), Staatsangehörigkeitsrecht im Wandel. Eine rechtsvergleichende Studie über die Erwerb- und Verlustgründe der Staatsangehörigkeit, 's-Gravenhage: T.M.C. Asser Instituut 1988/ Köln etc.: Carl Heymanns Verlag KG 1989.

- de Groot, Gerard-René (1989), Vergelijkt alles en behoudt het goede. Beschouwingen over onderwijs en onderzoek op het gebied van rechtsvergelijking. Inaugurale rede Maastricht, Deventer: Kluwer 1989.

- de Groot, Gerard-René (2007a), Achtentwintig Nederlanders, Bewerkte adviezen en casus over de toepassing van de Nederlandse nationaliteitswetgeving, 's-Gravenhage: Elsevier Overheid 2007.

- de Groot, Gerard-René (2007b), Identiteitsfraude en het Nederlanderschap van vóór 1 april 2003 genaturaliseerde personen, Nederlands Juristenblad (NJB) 2007, pp. 74-80.

- de Groot, Gerard-René (2012a), Preventing Statelessness among Children: Interpreting Articles 1-4 of the 1961 Convention on the Reduction of Statelessness and Relevant International Human Rights Norms, Background Paper, March 2012, Geneva: UNHCR.

- de Groot, Gerard-René (2012b), "Equality of Women and Men in Nationality Law", in Ingrid Westendorp (ed.), The Women's Convention Turned 30: Achievements, Setbacks and Prospects, Cambridge-AntwerpPortland: Intersentia, pp. 185-200.

- $\quad$ de Groot, Gerard-René (2013a), "UNHCR Guidelines 4: De interpretatie van het Verdrag tot beperking der staatloosheid uit 1961", Asiel- en Migrantenrecht, pp. 266-270.

- $\quad$ de Groot, Gerard-René (2013b), Avoiding Statelessness caused by Loss or Deprivation of Nationality: Interpreting Articles 5-9 of the 1961 Convention on the Reduction of Statelessness and Relevant International Human Rights Norms, Background paper, October 2013, Geneva: UNHCR.

- de Groot, Gerard-René (2013c), Survey on Rules on Loss of Nationality in International Treaties and Case Law, Background paper ILEC-project (project on Involuntary Loss of European Citizenship), CEPS Paper in 
Liberty and Security in Europe No. 57 (July 2013), available on http:// www.ceps.be/book/survey-rules-loss-nationality-international-treatiesand-case-law; also included as chapter 3, in: Sergio Carrera Nuñez and Gerard-René de Groot, European citizenship at the Crossroads: The Role of the European Union on Loss and Acquisition of Nationality, Oisterwijk: Wolf Legal Publishers 2015, pp. 9-39.

- de Groot, Gerard-René (2014a), "Strengthening the position of children: Council of Europe's Recommendation (2009)13", in Erik Witjens, Viola Van Bogaert and Carlos Bollen (eds), E hofi di ley, Den Haag: Boom Juridische uitgevers, pp. 467-493.

- de Groot, Gerard-René (2014b), "Children, their right to a nationality and child statelessness", in Alice Edwards and Laura van Waas (eds), Nationality and statelessness under international law, Cambridge: Cambridge University Press, pp. 144-168.

- de Groot, Gerard-René (2014c), "Verlies van het Nederlanderschap na tien jaar buitenland: problemen en oplossingen", Asiel- en Migrantenrecht 2014, pp. 86-93.

- de Groot, Gerard-René (2015), "Verlies van de nationaliteit wegens het wegvallen van familierechtelijke betrekking", in: Katharina Boele-Woelki e.d.(ed.), Actuele ontwikkelingen in het familierecht, Negende UCERF symposium, Nijmegen: Ars Aequi Libri 2015, pp. 89-111.

- de Groot, Gerard-René and Hildegard Schneider (2007), "Erschlichene Einbürgerungen, Identitätsbetrug und Entzug der Staatsangehörigkeit in Deutschland und den Niederlanden", in: Eckhart Klein/ Stefan Ulrich Pieper/ Georg Ress (ed.), Rechtsstaatliche Ordnung Europas Gedächtnisschrift für Albert Bleckmann, Köln: Carl Heymanns 2007, pp. 79-102.

- de Groot, Gerard-René and Anja Seling (2011), "The consequences of the Rottmann judgment on Member State autonomy - The European Court of Justice's avant-gardism in nationality matters", European Constitutional Law Review 2011, 150-160; also published in: Jo Shaw (ed): Has the European Court of Justice Challenged Member State Sovereignty in Nationality Law? (RSCAS Working Paper 2011/62), Florence: EUI 2011, pp. 27-31, also available on: http://cadmus.eui.eu/handle/1814/19654.

- de Groot, Gerard-René and Maarten Vink (2014), Meervoudige nationaliteit in Europees perspectief, Een landenvergelijkend overzicht, 's Gravenhage: Adviescommissie voor Vreemdelingenzaken, Voorstudie 19-2008, $182 \mathrm{p}$. 
- de Groot, Gerard-René and Maarten Vink (2014), A Comparative Analysis of Regulations on Involuntary Loss of Nationality in the European Union, Background paper ILEC-project (project on Involuntary Loss of European Citizenship), CEPS Paper in Liberty and Security in Europe No. 75 (December 2014), available on http://www.ceps.be/book/surveyrules-loss-nationality-international-treaties-and-case-law; also included a chapter 3, in: Sergio Carrera Nuñez and Gerard-René de Groot, European citizenship at the Crossroads: The Role of the European Union on Loss and Acquisition of Nationality, Oisterwijk: Wolf Legal Publishers 2015, pp. 41-116.

- de Groot, Gerard-René and Olivier Vonk (2012), Nationality, statelessness and ECHR's Article 8: Comments on Genovese v Malta, European Journal of Migration and Law, pp. 317-325.

- de Groot, Gerard-René and Olivier Vonk (2015), “Ontneming van het Nederlanderschap wegens jihadistische activiteiten" in Tijdschrift voor Religie, Recht en beleid 2015, pp. 34-53; also published in: Maurits S. Berger (ed.), Nederlanders in de heilige oorlog: zoeaven, brigadisten en jihadisten, Boom juridische uitgevers 2015, pp. 109-134.

- de Groot, Gerard-René and Olivier Vonk (2016a), "Jihad en ontneming van nationaliteit: Nederlandse plannen in vergelijkend perspectief", bewerking van een lezing gehouden tijdens het drieëndertigste symposium van de Vereniging ter bestudering van het Recht van de Islam en het Midden Oosten (RIMO), gehouden te Leiden op 2 juli 2015, in: Pauline Kruiniger (ed.), Jihad, Islam en Recht, RIMO-bundel 2015, Den Haag: Boom Juridische Uitgevers 2016.

- de Groot, Gerard/René and Olivier Vonk (2016b), International standards on nationality law: Texts, Cases and Materials, Oisterwijk Wolf Legal Publishers.

- de Groot, Gerard-René , Katja Swider and Olivier Vonk (2015), Practices and approaches in EU Member States to prevent and end statelessness, Study for the European Parliament (Directorate general for internal policies; Policy department C: Citizens' rights and constitutional affairs; Civil liberties, Justice and Home Affairs, Brussels: European Parliament 2015, available on http://www.europarl.europa.eu/studies.

- de Groot, Gerard-René and Patrick Wautelet (2014), Reflections on Quasi-loss of nationality from comparative, international and European perspective, Background paper ILEC-project (project on Involuntary Loss of European Citizenship), CEPS Paper in Liberty and Security in Europe No. 66 (August 2014), also available on http://www.ceps.eu/publications/ 
reflections-quasi-loss-nationality-comparative-international-and-europeanperspective ; also included a chapter 4, in: Sergio Carrera Nuñez and Gerard-René de Groot, European citizenship at the Crossroads: The Role of the European Union on Loss and Acquisition of Nationality, Oisterwijk: Wolf Legal Publishers 2015, pp. 117-157.

- Dumbrava, Costica and Rainer Bauböck (2015), Bloodlines and belonging: Time to abandon ius sanguinis?, EUI Working Papers, RSCAS 2015/80, Robert Schuman Centre for Advanced Studies, EUDO Citizenship Observatory, available on http://cadmus.eui.eu/bitstream/ handle/1814/37578/RSCAS_2015_80.pdf?sequence=1\&isAllowed=y.

- Edwards, Alice (2014), "The meaning of nationality in international law in an era of human rights: procedural and substantive aspects", in Alice Edwards and Laura van Waas (eds), Nationality and statelessness under international law, Cambridge: Cambridge University Press, pp. 11-43.

- Edwards, Alice and Laura van Waas (eds) (2014), Nationality and statelessness under international law, Cambridge: Cambridge University Press.

- Ersbøll, Eva (2015), "Retain ius sanguinis, but don't take it literally!", in: Dumbrava, Costica and Rainer Bauböck (2015), Bloodlines and belonging: Time to abandon ius sanguinis?, EUI Working Papers, RSCAS 2015/80, Robert Schuman Centre for Advanced Studies, EUDO Citizenship Observatory, pp. 35-38, available on http://cadmus.eui.eu/ bitstream/handle/1814/37578/RSCAS_2015_80.pdf? sequence=1\&is Allowed $=\mathrm{y}$

- European Network on Statelessness (2013), “Good Practice Guide to Statelessness Determination and the Protection Status of Stateless Persons", available on www.statelessness.eu/sites/www.statelessness.eu/ files/attachments/resources/Statelessness $\% 20$ determination $\% 20$ and $\% 20$ the $\% 20$ protection $\% 20$ status $\% 20$ of $\% 20$ stateless $\% 20$ persons $\% 20$ ENG.pdf.

- European Network on Statelessness (2015), "No Child should be Stateless", available on www.statelessness.eu/sites/www.statelessness.eu/ files/ENS_NoChildStateless_final.pdf.

- Thomas Faist and Peter Kivisto (ed.), Duals Citizenship in Global Perspective: from Unitary to Multiple Citizenship, Basingstoke/ Houndmills: Palgrave Macmillan 2007.

- Goodman-Gill, Guy (2014), Mr. Al-Jedda, Deprivation of Citizenship and International Law, revised draft of a paper presented at 
Middlesex University, 14 February 2014, available on http://www. parliament.uk/documents/joint-committees/human-rights/GSGGDeprivationCitizenshipRevDft.pdf

- $\quad$ Randall Hansen and Patrick Weil (ed), Dual Nationality, Social Rights and Federal Citizenship in the U.S. and Europe, London: Macmillan, 2001

- Jessurun d'Oliveira, Hans Ulrich (1978), Bijdrage aan het Debat over het pre-advies van Mr. G.R. de Groot, Gelijkheid van man en vrouw in het nationaliteitsrecht, Nederlandse Vereniging voor Rechtsvergelijking nr. 26, Deventer: Kluwer 1978, pp. 37-39.

- Jessurun d'Oliveira, Hans Ulrich (1989), "Tendenzen in Europees nationaliteitsrecht”, Nederlands Juristenblad 1989, pp. 357-361.

- Jessurun d'Oliveira, Hans Ulrich (1990), “Tendenzen im Staatsangehörigkeitsrecht“, Zeitschrift für Ausländerrecht 1990, pp. 114-119.

- Jessurun d'Oliveira, Hans Ulrich (2011), "Decoupling Nationality and Union Citizenship?”, European Constitutional Law Review 2011, pp. 138-149.

- Jessurun d'Oliveira, Hans Ulrich (2013), “Gerard-René de Groot vijfentwintig jaar hoogleraar", in: Kees Saarloos en Susan Rutten (ed.), Van afstamming tot nationaliteit, Opstellen aangeboden aan professor mr. G.R. de Groot, ter gelegenheid van zijn 25-jarig ambtsjubileum als hoogleraar rechtsvergelijking en internationaal privaatrecht aan de Universiteit Maastricht, Deventer: Kluwer, pp. 1-8.

- Jessurun d'Oliveira, Hans Ulrich (2016), Automatisch verlies nationaliteit voor Nederlander buitenaf onhoudbaar, Nederlands Juristenblad 2016, pp. 248-255.

- Lambert, Hélène (2015), "Comparative perspectives on arbitrary deprivation of nationality and refugee status", ICLQ 2015, pp. 1-37.

- Laurent, François (1887), Principes de droit civil français, tome 1, 4th edition, Bruxelles/ Paris : Bruylant/ Marescq.

- Macklin, Audrey, and Rainer Bauböck (2015), eds. The Return of Banishment: Do the New Denationalisation Policies Weaken Citizenship?, Rscas 2015/14, 2015, available on http://cadmus.eui.eu/bitstream/ handle/1814/34617/RSCAS_2015_14.pdf?sequence=1. 
- Manby, Bronwen (2015), Citizenship and statelessness in Africa: The law and politics of belonging, Oisterwijk: Wolf Legal Publishers 2015.

- Manly, Mark and Laura van Waas (2014), "The State of Statelessness Research. A Human Rights Imperative", Tilburg Law Review 19, No. 1-2, pp. 3-10.

- Molnár, Tamás (2014), “The Prohibition of Arbitrary Deprivation of Nationality under International and EU Law: New Perspectives", Hungarian Yearbook of International Law and European Law, pp. 67-92.

- Pitkänen, Pirrko and Devorah Kalekin-Fishman, Multiple State Membership and Citizenship in the Era of Transnational Migration. Rotterdam/ Taipei: Sense Publishers 2007.

- Sawyer, Caroline and Brad K. Blitz (eds) (2011), Statelessness in the European Union. Displaced, Undocumented, Unwanted. Cambridge: Cambridge University Press.

- Shaw, Jo (2011), "Setting the scene: the Rottmann case introduced", in: Jo Shaw (ed): Has the European Court of Justice Challenged Member State Sovereignty in Nationality Law? (RSCAS Working Paper 2011/62), Florence: EUI 2011, pp. 1-4, also available on: http://cadmus.eui.eu/ handle/1814/19654.

- Stiller, Martin (2011), Eine Völkerrechtsgeschichte der Staatenlosigkeit: Dargestellt anhand ausgewählter Beispiele aus Europa, Russland und den USA, Wien: Springer.

- van Waas, Laura (2008), Nationality Matters. Statelessness under international law, Antwerp: Intersentia, also available on http://arno.uvt. nl/show.cgi?fid=113179.

- van Waas, Laura (2011), "Nationality and rights", in Brad K. Blitz and Maureen Lynch, Statelessness and Citizenship. A comparative Study on the Benefits of Nationality, Cheltenham: Edward Elgar, pp. 23-44.

- $\quad$ van Waas, Laura (2012), "Fighting Statelessness and Discriminatory Nationality Laws in Europe", European Journal of Migration and Law 14, No. 3, pp. 243-260.

- $\quad$ van Waas, Laura (ed.) (2014), "Special issue on statelessness", Tilburg Law Review 19, No. 1-2, pp. 3-315. 
- Vink, Maarten and Gerard-René de Groot (2010a), "Citizenship attribution in Western Europe: International framework and domestic trends", Journal of Ethnic and Migration Studies 2010, 713-734; also published in: Maarten Peter Vink (ed.), Migration and Citizenship Attribution, Politics and Policies in Western Europe, London and New York: Routledge 2012, pp. 1-22

- Vink, Maarten and Gerard-René de Groot (2010b), Birthright citizenship, Trends and regulations in Europe, November 2010, EUDO Citizenship Observatory, Robert Schuman Centre for Advanced Studies/ Edinburgh University Law School, Comparative Report, RSCAS/EUDO-CIT-Comp. 2010/6, 36 p., available on http://eudo-citizenship.eu.

- Vonk, Olivier (2012), Dual nationality in the European Union, Leiden/ Boston: Martinus Nijhoff Publishers.

- Vonk, Olivier (2014), Nationality law in the Western Hemisphere; A study on the grounds for acquisition and loss of citizenship in the Americas and the Caribbean, Leiden/ Boston: Brill/ Martinus Nijhoff Publishers.

- Vonk, Olivier, Maarten Vink and Gerard-René de Groot (2013), "Protection against statelessness: Trends and regulations in Europe", EUDO Citizenship Comparative Report, also available on http://eudocitizenship.eu/images/docs/eudocit_vink_degroot_statelessness_final.pdf.

- Vonk, Olivier, Maarten Vink and Gerard-René de Groot (2014), "Benchmarking the Protection against Statelessness in Europe: Comparative Findings", Tilburg Law Review 19, No. 1-2 pp. 294-302.

- Wautelet, Patrick (2015), "Priver les djihadistes de leur nationalité belge: les garde-fous à respecter", available on http://www.ilecproject.eu/sites/ default/files/JT\%206593\%20pp\%20183\%20184\%20\%282015\%29.pdf.

- Wautelet, Patrick (2016), Deprivation of citizenship for 'jihadists'. Analysis of Belgian and French practice and policy in light of the principle of equal treatment, lezing gehouden tijdens het drieëndertigste symposium van de Vereniging ter bestudering van het Recht van de Islam en het Midden-Oosten (RIMO), gehouden te Leiden op 2 juli 2015, in: Pauline Kruiniger (ed.), Jihad, Islam en Recht, RIMO-bundel 2015, Den Haag: Boom Juridische Uitgevers 2016.

- Wells-Greco, Michael (2015), The Status of Children arising from InterCountry Surrogacy Arrangements: The Past, the Present, the Future, $\mathrm{PhD}$ dissertation, Maastricht University, Eleven International Publishing: The Hague. 
